\title{
The Effect of HWVP Feed Nitrate and Carbonate Content on Glass
} Redox Adjustment

K. D. Wiemers

March 1996

Prepared for the U.S. Department of Energy under Contract DE-AC06-76RLO 1830

Pacific Northwest National Laboratory Operated for the U.S. Department of Energy by Battelle Memorial Institute 
PNNL-11044

UC-810

Project Technical Information

\title{
The Effect of HWVP Feed Nitrate and Carbonate Content on Glass Redox Adjustment
}

\author{
K. D. Wiemers .
}

- March 1996

Prepared for

the U.S. Department of Energy

under Contract DE-AC06-76RLO 1830

Pacific Northwest National Laboratory

Richland, Washington 99352

Reprint of historical document HWVP-90-1.2.2.03.03A, dated April 1990. Data, formatting, and other conventions reflect standards at the original date of printing. Technical peer reviews and editorial reviews may not have been performed. 


\title{
DISCLAISAER
}

This report was prepared as an account of work sponscred by an agency of the United Staies Gol ernment. Neither the United States Government nor any agency thereof, nor Earielle Wiemorial Instituie, nor any of their emplojees, makes any H'arranty, express or implied, or assumes ariy legal liability or responsibility for the accuracy, completeness, or.usefulness of any information, apparaius, product, or process disclosed, or represents that its use hould not infringe privately orined rights. Ref́erence heiein io any speciñc commercial product, process, or service by iráde name, irácemark, menuíaciurer, or othenvise cüuss not necessarily consitute or imply its endorsement, recommendation, or fevoring by the Lnited States Government or any agency thereof, or Banielle Niemorial Instiulie. The view's and opinions of authors expressed herein do not necessarily staie or reflect those of the United States Government or any agency thereor.

\author{
PACIFIC NORTHWEST NATIONAL LABORATORY \\ operäited by \\ BATTELLE \\ for the \\ UNITED STATES DEPARTMENT OF ENERCY \\ under Contract DE-AC06-76RLO 1830
}

Printed in the United States of America

Available to DOE and DOE contractors from the

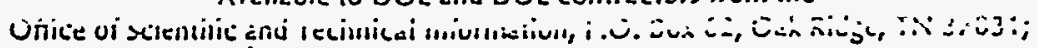
prices, available from (615) 576-8401.

Available to the public from the National Technical information Service, U.S. Department of Commerce, 5285 Port Royal Rd., Springfield, VA 22161 


\section{CONTENTS}

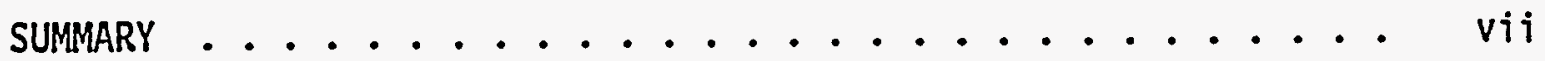

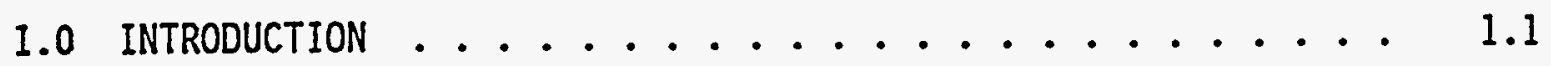

2.0 CONCLUSIONS AND RECOMMENDATIONS .................... 2.1

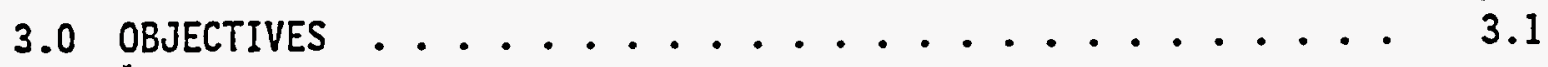

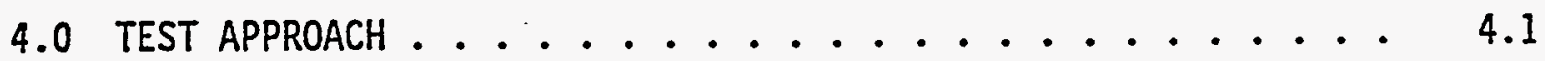

4.1 BASIS FOR TEST PARAMETERS . . . ...... 4.1

4.2 TEST MATRICES . . . . . . . . . . 4.2

4.3 TEST SIMULANT PREPARATION . . . . . . . . 4.4

4.4 FORMATING AND VITRIFICATION PROCEDURE $\ldots \ldots \ldots . . \ldots 4$

4.5 ANALYTICAL TESTS . . . . . . . . . . 4.6

5.0 EQUIPMENT DESCRIPTION . . . . . . . . . . 5.1

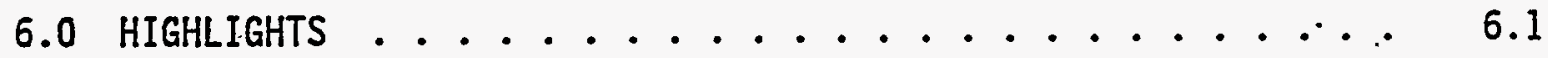

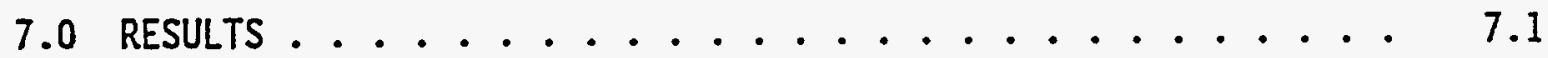

7.1 SIMULANT COMPOSITION . . . . . . . . . 7.1

7.2 PHYSICAL CHARACTERISTICS . . . . . . . 7.5

$7.2 .1 \mathrm{pH} \mathrm{Data} \mathrm{.} \mathrm{.} \mathrm{.} \mathrm{.} \mathrm{.} \mathrm{.} \mathrm{.} \mathrm{.} \mathrm{.} \mathrm{.} 7.5$

7.2 .2 Rheology ................ 7.5

7.2.3 Density, \% Total Solids, \% Total Oxide, . . . . . . . . . 7.9
and Total Oxide/L . . . . . .

7.3 CHEMISTRY OF THE HWVP FORMATING STEP . . . . . . 7.11

7.3.1 Redox Reactions ............. 7.11

7.3.2 Hydrolysis Chemistry . . . . . . . . 7.14

7.4 SOLUBILITY MEASUREMENTS . . . . . . . . . 7.18

7.4.1 Ions that Increase in Solubility After

Formating ..................... 7.18 
7 7.4.2 Ions that Decrease in Solubility After Formating ............ 7.23

7.4.3 Proposed Reaction Scenario for Chromium . . . 7.24

7.5 FORMIC ACID REQUIREMENTS . . . . . . . . . 7.25

7.6 MASS BALANCE .................... 7.29

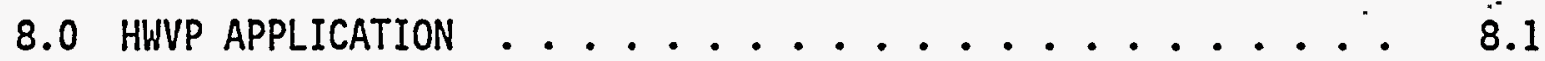

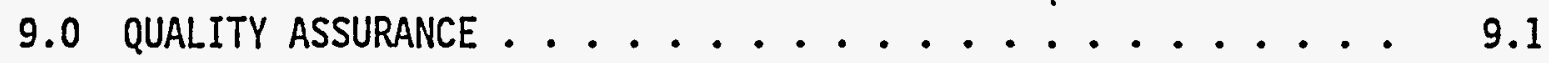

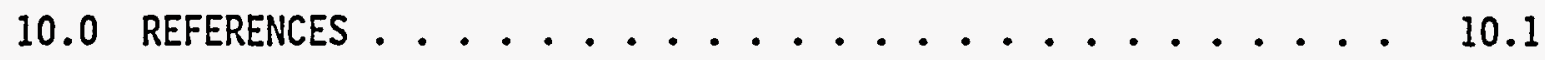




\section{FIGURES}

5.1 Schematic of the Formating Apparatus ......... 5.1

$7.1 \mathrm{pH}$ Change During Formic Acid Addition for

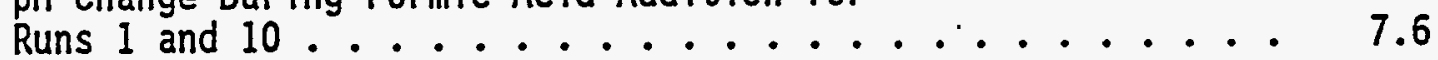

7.2 Comparison of Apparent Viscosity as a Function of Shear
Rate for Initial and Formated Simulants . . . . . 7.9

7.3 Dependence of Glass Redox on $\mathrm{HCOOH} / \mathrm{NO}_{3} \ldots \ldots . . . . . .7 .26$

7.4 Threshold for $\mathrm{HCOOH} / \mathrm{NO}_{3}$ and $\mathrm{Fe}+2 / \mathrm{Fe}^{+3}$ Relationship .... 7.27

7.5 Preliminary Mass Balance Flowsheet for Run $12 \ldots . . \ldots 7.32$

7.6 Preliminary Mass Balance Flowsheet for Run $13 \ldots . . . . .7 .33$

7.7 Nitrate Reduction Efficiency During Formating ...... 7.34

7.8 Relationship Between Ferrous Ion, Nitrate, and

Formic Acid ................. 7.35 


\section{IABLES}

4.1 Range for Test Parameters . . . . . . . . . . 4.3

4.2 Simulant Target Composition ........... 4.5

7.1 Composition of Test Simulant for Runs $1-10, \mathrm{~g} / \mathrm{L} \ldots . . .7 .2$

7.2 Composition of Formated Simulant for Runs $1-10, \mathrm{~g} / \mathrm{L} \ldots . .3 .3$

7.3 Run 11 Compositional Data, g/L . . . . . . . . 7.4

7.4 Rheology Measurements for Simulant Up Curve . . . . . 7.7

7.5 Rheology Measurements for Simulant Down Curve . . . . . 7.7

7.6 Rheology Measurements for Formated Simulant . . . . . . 7.8

7.7 Physical Properties of Test Simulants ........ 7.10

7.8 Free Energy of Formation . . . . . . . . . 7.14

7.9 SolubiTity Constants for HWVP Feed Components . . . . 7.15

7.10 Formation Constants for Hydrated Oxides in ....... 7.19

7.11 Solubility Constants for Hydroxide Salts in
HWVP Feed . . . . . . . . . . . . . . . . .

7.12 Solubility Data for Runs 12 and $13 \ldots \ldots . \ldots . . . . . .21$

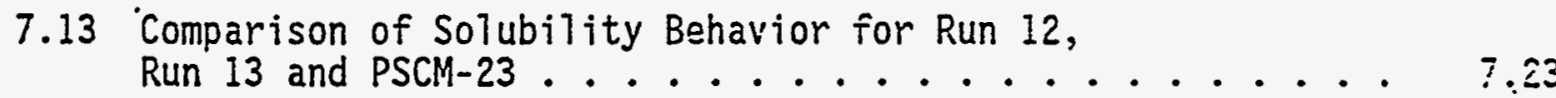

$7.14 \mathrm{HCOOH/NO3} \mathrm{Threshold} \mathrm{Support} \mathrm{Data} \mathrm{.} \mathrm{.} \mathrm{.} \mathrm{.} \mathrm{.} \mathrm{.} \mathrm{.} \mathrm{.} 7.28$

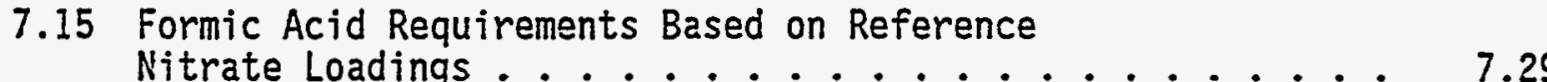

7.16 Run 12 (Low Carbonate Loading) . . . . . . . . 7.31 


\section{SUMMARY}

The Hanford Waste Vitrification Plant (HWVP) is being designed for the Department of Energy to immobilize pretreated radioactive high-level waste (HLW) as glass for geological disposal. In the HWV formic acid will be added to the pretreated HLW prior to vitrification. The formic acid is added to adjust the feed rheology and to provide a reductant which maintains the feed in the melter within an acceptable redox range. This study was conducted to evaluate the effect of nitrate and carbonate concentrations in the pretreated neutralized current acid waste (NCAW) feed on the amount of formic acid required to obtain an acceptable glass redox state in the melter. The glass redox state was measured by the $\mathrm{Fe}^{+2} / \mathrm{Fe}^{+3}$ ratio in the vitrified product.

Thirteen runs were conducted, providing 19 data points. The physical properties and chemical composition of preformated and formated test simulants were characterized. The redox state of the vitrified product was evaluated as a function of formic acid addition for different combinations of nitrate and carbonate content in the feed. Data from this study and Farnsworth (1987) were compiled to evaluate the relationship between formic acid addition requirements, nitrate concentration, and glasss redox adjustment. Results from this study suggest that the formic acid requirements are more accurately prescribed by the stoichiometry of redox reactions rather than neutralization reactions. The primary recos participants in this study were nitrate, ferric ion, and formic acid. An acceptable glass redox was observed when $\mathrm{HCOOH} / \mathrm{NO}_{3}=3$ and $\mathrm{Fe} / \mathrm{NO}_{3} \leq 4$. In the presence of high iron $\left(\mathrm{Fe} / \mathrm{NO}_{3}>4\right)$ the formic acid requirements for acceptable glass redox were less, $\mathrm{HCOOH} / \mathrm{NO}_{3}=1.5$ to 2.5 . It is speculated that the variation in the formic acid requirements can be correlated to differences in the ratio of nitrate redox reaction products, $\mathrm{NO}, \mathrm{NO}_{2}, \mathrm{~N}_{2} \mathrm{O}$ and $\mathrm{NH}_{3}$. Wiemers (1987) reported the presence of $\mathrm{CO}_{2}, \mathrm{NO}_{x}, \mathrm{~N}_{2} \mathrm{O}$, and $\mathrm{H}_{2}$ in offgas released during formating. Ammonia was qualitatively detected during the study reported herein. The relationship of other active redox species such as nitrite and organics to formic acid requirements for giass redox remains to be established. . 
The threshold requirement, $\mathrm{HCOOH} / \mathrm{NO}_{3}=3$, was independent of the simulant carbonate content. The carbonate. content ranged from 6 to $39 \mathrm{~g}$ carbonate/g Wo (8 to $54 \mathrm{~g}$ carbonate/L). Thus, formic acid adjustments for glass redox are not required. However, evaluation of 1 imited mass balance data suggests that the step in which nitrate reduction occurs (formating or vitrification) may be dependent on the $\mathrm{pH}$ (i.e., carbonate content) of the feed. Lower nitrate consumption during formating was observed in high carbonate (more alkaline) simulants.

The physical properties of the feed were similar to those observed for PSCM-23 (GoTes 1989). No apparent trends related to nitrate or carbonate concentration were observed for the physical properties measured during this study.

The control of glass redox behavior couples two chemical systems: 1) formating during which formic acid is added to the feed and 2) vitrification, the product from which the $\mathrm{Fe}^{+2} / \mathrm{Fe}^{+3}$ ratio is measured. A preliminary mass balance flowsheet was derived which begins to tie together the chemistry of these two systems. 


\subsection{INTRODUCTION}

The Hanford Waste Vitrification Plant (HWVP) is being designed for the Department of Energy to immobilize pretreated radioactive high-level waste (HLW) as glass for geological disposal. Formic acid will be added to the pretreated HLW in the HWVP prior to vitrification. The formic acid is added to adjust the feed rheology and to provide a reductant which maintains the glass redox state in the melter within an acceptable redox range. A sufficient quantity of reducing agent is needed to assure that the glass will not foam by reboil in the melting process, thereby decreasing process rates. Excess reducing agent will result in the reduction of metal oxides to their metallic state. The reduced metals can form a conductive sludge at the bottom of the ceramic melter; shorting the melter electrodes; leading to premature failure of the meiter.

Experimental work was conducted to determine the relationship between the nitrate and carbonate concentration in a test simulant and the amount of formic acid necessary to provide an acceptable glass redox state. The glass redox state is measured by the $\mathrm{Fe}^{+2} / \mathrm{Fe}^{+3}$ in the vitrified sample. A $\mathrm{Fe}^{+2} / \mathrm{Fe}^{+3}$ range of 0.005 to 0.3 has been found to provide acceptable glass behavior for melter operation. The test simulant prepared in this study was based on a reference pretreated NCAW composition with the exception of not contairing nitrite or organics. The adjustmenis in formic acid addition required for nitrite and organics remain to be defined.

This study addresses Technology PTan (Sexton 1988) issue 2.2.1 Redox Control and was originat7y authorized in the fiscal year (FY) 1989 Letter of Instruction to Pacific Northwest Laboratory (PNL) under WBS 1 VJ0010300. Additional experimental work was performed per the FY 1990 Letter of Instruction under WBS 1.2.2.03.03. This report satisities the requirements for deliverable 1.2.2.03.03A, "Issue report on glass redox behavior as a function of feed components."

This report describes the test approach, apparatus; and measurements; and discusses the results in terms of formating chemistry and plant application. Conclusions and recommendations are listed first. 


\subsection{CONCLUSIONS AND RECOMMENDATIONS}

The following conclusions are made from the results and analyses of this study.

- An acceptabie glass redox was observed when $\mathrm{HCOOH} / \mathrm{NO}=3$ and $\mathrm{Fe} / \mathrm{NO3} \leq 4$. In the presence of high iron ( $\mathrm{Fe} / \mathrm{NO3}>4$ ) (Farnsworth. 1987) the formic acid requirements for an acceptable glass redox were less, $\mathrm{HCOOH} / \mathrm{NO}=1.5$ to 2.5 .

- The presence of ammonia in formated simulant indicates a higher degree of nitrate reduction than previousiy reported in Wiemers 1987. Reduction of nitrate to ammonia would require more formic acid stoichiometrically, than reduction of nitrate to gaseous nitric oxides. The amount of $\mathrm{NH}_{3}$ produced was not quantified in this study.

- The threshold requirement, $\mathrm{HCOOH} / \mathrm{NO}=3$ was independent of the carbonate concentration. Thus, no formic acid adjustments for glass redox are required to accommodate the presence of carbonate in the range of 6 to $39 \mathrm{~g}$ carbonate $/ \mathrm{g}$ WO (8 to $54 \mathrm{~g}$ carbonate $/ \mathrm{L}$ ).

- High levels of carbonate resulted in more alkaline endpoints for equivalent formic acid additions. The minimum $\mathrm{pH}$ in high carbonate samples was 5. At an equivalent formic acid addition to low carbonate s7urries the minimum $\mathrm{pH}$ was 3 . Based on limited mass balance data, the amount of nitrate reduction during the formating step increased with an increase in acidity (low carbonate simulants). However, as noted above, the threshold requirement for $\mathrm{HCOOH} / \mathrm{NO}_{3}$ was independent of carbonate loading.

- Evaluation of solubitity behavior suggests that $25-50 \%$ of the chromium, manganese, and molybdenum are reduced during formating.

- The physical properties of the simulant were similar to those reported for PSCM-23 (Goles and Nakaoka. 1989). No apparent trends related to nitrate or carbonate concentration were observed for the physical properties measured.

The following recommendations are made based on the results of this study:

- Hanford high-7evel wastes to be treated in the HWVP will contain nitrite and organics. The effects of these components on the current correlation for redox adjust chemical requirements needs to be investigated. Off gas analysis should be included in these studies. 
- Current plans are to add a maximum of $30 \mathrm{ml} 90 \mathrm{wt} \%$ formic acid; additional reductant would be supplied by sugar. These redox adjustment components were used successfuily during PSCM-23 (Goles and Nakoaka, 1990) after lab-scale testing to establish requirements. Assessment of the supplemental reductant requirements should be firmly established now via lab-scale studies to minimize lag time during actual processing.

- Glass redox in the melter is significantiy affected by the melter. environment, cold cap chemistry, and glass/cold cap dynamics.

- Correlation of glass redox models from laboratory studies with large scale feed processing and melter operation is required to ensure the validity of correlations for HWVP feed makeup.

- The amount of ammonia released during formating should be quantified. The impact of ammonia release during formating on the off gas ventilation system needs to be considered. The potential for formation of ammonia nitrate on filters may propose some safety concerns. The dissolution of ammonia in the scrubber may alter the scrubbers trapping efficiency.

- The generation rate of $\mathrm{H}_{2}$ and any organics needs to be further defined in order to assess if the explosion Timit can be approached during formating. The release of $\mathrm{H}_{2}$ during formating has been discussed. Co was not detected above 0.1 mole\% (detection limit for mass spectroscopy analysis) in the off gas collected during formating (Wiemers 1987).

- Nitrate reduction may occur in the SRAT and/or in the melter. The dependence of melter throughput on where the nitrate reduction occurs requires evaluation.

- The potential for magnetic particles to impact subsequent process steps should be considered. 


\subsection{OBJECTIVE}

The objective of this study was to provide a predictive model by which the amount of formic acid required to obtain an acceptable glass redox state may be determined based on the nitrate and carbonate composition of the feed. The redox state of the vitrified product was evaluated as a function of three key variables: concentrations of carbonate and nitrate in the feed and the amount of formic acid added. 


\subsection{TEST APPROACH}

Ten runs were conducted to complete a parametric test in which the $\mathrm{Fe}^{+2} / \mathrm{Fe}^{+3}$ of vitrified samples was measured for various combinations of nitrate and carbonate simulant content and amounts of formic acid added. Results from this initial test indicated that redox reactions rather than neutralization reactions should provide the primary basis for specifying formic acid requirements for glass redox adjustments. Subsequently, three additional runs were completed in which the amount of formic acid added was based on the initial nitrate concentration. Nitrate was the major oxidant in the test simulants.

This section describes the selection criteria for the test parameters; the test matrix; the feed preparation and formating procedures; and the analyses.

\subsection{BASIS FOR TEST PARAMETERS}

Sources of nitrate and carbonate in the actual waste and bounding case concentration levels as estimated by Westinghouse Hanford Company (WHC) are based upon core sample analyses and flowsheet evaluation. These data are reported in the Hanford Waste Vitrification P1ant Technical Data Package (Wright 1988). A summary of the selection criteria is given for the bounding cases used in this study.

Nitrate - The primary source of nitrate in the NCAK is the nitric acid used in the PUREX Plant during the dissolution and processing of the fueT. In the B-PTant the waste will be washed to remove nitrate to meet HWV acceptance criteria. Target bounding case concentration levels estimated by WHC and used in this study were 3 to $36 \mathrm{~g} \cdot \mathrm{NO}_{3} / 100 \mathrm{~g}$ waste oxides. The nominal concentration of nitrate was $9 \mathrm{~g} \mathrm{NO}_{3} / 100 \mathrm{~g}$ waste oxides. The high and nominal concentrations were obtained from the Technical Data Package (Wright. 1988). The target minimum nitrate concentration is based on the nitrate remaining after washing of the precipitated hydroxides during simulant preparation (Wiemers 1987).

Carbonate - NCAW is currently stored in double she11 tanks (DST). After pretreatment in B-Plant, the waste will be stored in DST prior to routing to 
the HWVP: During storage in the double she11 tanks, air lift circulators are used to prevent the accumulation of excessive heat from radiolytic decay by suspending solids and removing heat by forced convection. Equilibration of the HWVP feed with carbon dioxide from the air is the primary source of carbonate in the feed. The target range used in this study was 3 to $30 \mathrm{~g} / 100 \mathrm{~g}$ waste oxides. The low end of this range represents dissolved $\mathrm{CO}_{2}$ from the surrounding laboratory air. The target nominal $\mathrm{CO}_{3}$ concentration level was $17 \mathrm{~g} / 100 \mathrm{~g}$ oxides. The nominal and maximum levels of $\mathrm{CO}_{3}$ were obtained from a memo to 0 . L. Kruger from R. A. Watrous dated March 1, 1989. concerning Engineering Change Notices 400073 and 400074.

- Formic Acid - For the parametric test minimum (first 10 runs) selection of the formic acid addition, $16 \mathrm{~m} 790 \mathrm{wt} \%$ formic acid/L feed, assumed a $\mathrm{Fe}^{2+} / \mathrm{Fe}^{3+}$ ratio of 0.10 would be achieved (see Figure 7 , Farnsworth 1987). The nominal level. was $22 \mathrm{ml} 90 \mathrm{wt} \%$ formic acid/L as used for the similar simulant feed composition during PSCM-23 (Goles and Nakaoka 1989). (a) The . maximum level of formic acid addition was defined as the amount of formic acid required to reach a $\mathrm{pH}$ of 7 (essentially neutralize the added bicarbonate) with a high carbonate, low nitrate feed. This amount was $31 \mathrm{~m} 7$ $90 \mathrm{wt} \%$ formic acid/L.

For the 3 runs which followed the parametric test, the amount of formic acid added was besed on the initial nitrate concentration. The ratio, $\mathrm{HCOOH} / \mathrm{NO}_{3}$, ranged from 1.5 to 10 to bound the initial predicted threshold, $\mathrm{HCOOH} / \mathrm{NO}_{3}=3$, for obtaining an acceptabie glass redox state.

\subsection{IEST MATRICES}

This study consisted of thirteen runs. The first ten runs were defined by a parametric design. Based on results from the parametric test and

(a) Differences in simulant composition are: $-2 X$ more La in PSCM-23; Nd in PSCM-23 = $-3 / 4$ of current study; $Z n$ included in PSCM-23 not in current study; noble metals included in current study not in PSCM-23 (refer to Table 4.1 (Goles and Nakaoka 1989) with Table 4.2 of this report). 
analyses of Farnsworth 1987 data, three additional runs were performed to provide supplemental data. A summary of parameters used in each of the runs is given in TabTe 4.1 .

The experimental matrix for the parametric test as described in Test Plan HWVP-89-IVJ00100300A was revised as $\mathrm{NaNO}_{3}$ and $\mathrm{NaHCO}_{3}$ levels specified by the design would have resulted in sodium concentrations above the range of the reference sodium composition. Per the Test Plan the maximum amount of formic acid added during the parametric test was defined as that required to neutralize the high level carbonate/low level nitrate simulant (Test 6). Neutralization was defined as the point at which the slurry $\mathrm{pH}$ became $<7$.

TABLE 4.1. Range for Test Parameters

Slurry Composition

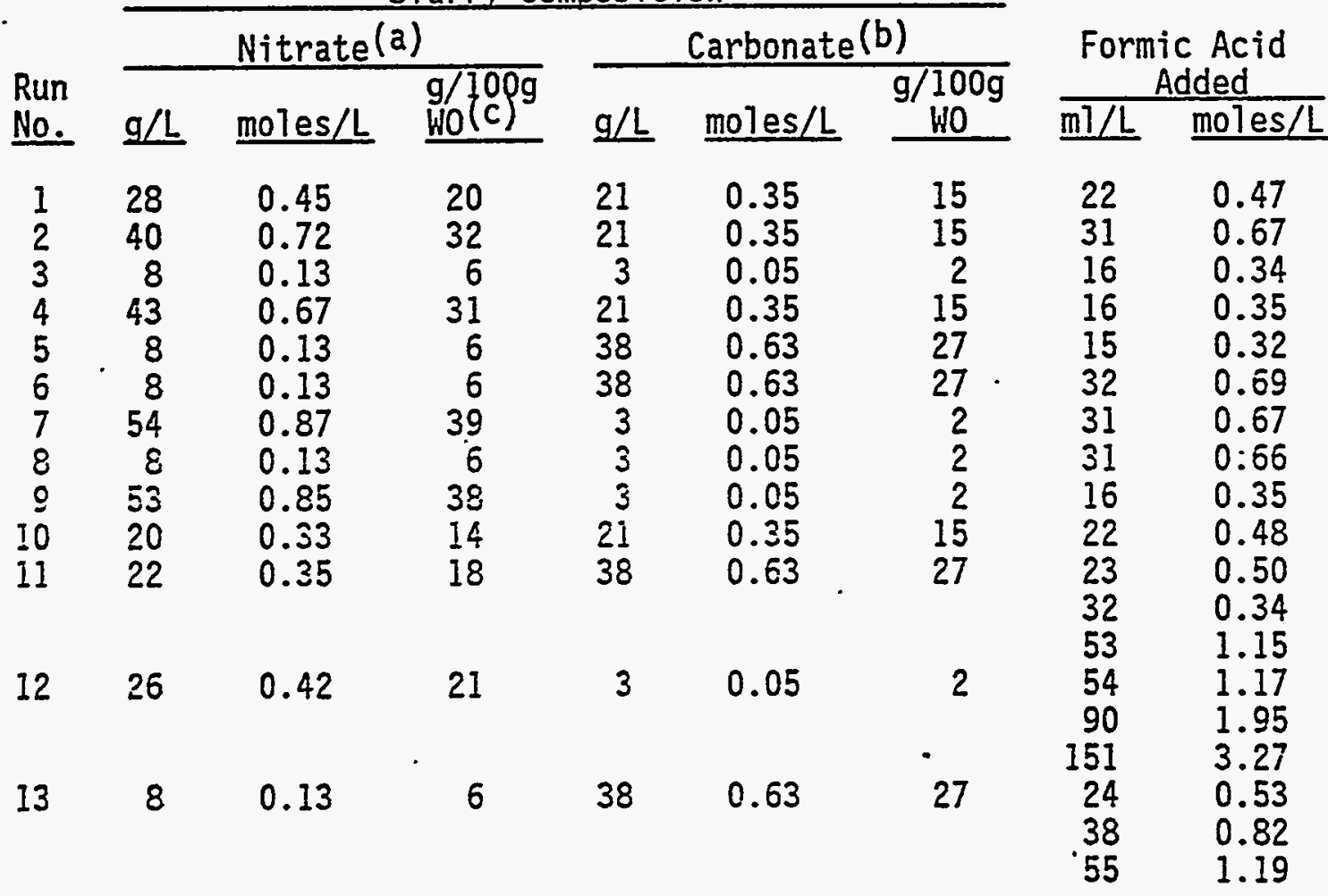
(a) Nitrate values reported from analytical data.
(b) High and nominal carbonate values are based on target composition. Low carbonate value based on analytical data may be in error by $50 \%$.
(c) Runs 1-10 simulants were.140 g waste oxide (WO)/L prior to formatting. Runs $11-13$ simulants were adjusted to 125 gWO/L prior to formatting.


However, the application of this formic acid loading, 31 to $32 \mathrm{ml} 90 \mathrm{wt} \%$ $\mathrm{HCOOH} / \mathrm{L}$ feed, resulted in only two of the ten runs (Run 6 and Run 8) with ferrous ion above the detection level (ferrous/ferric $\geq 0.005$ ). Insufficient data were availabie for statistical analysis.

Subsequentiy, three follow-up experiments were completed (Runs 11-13). These runs differed from the previous parametric study in two ways:

1. The formating procedure and apparatus were modified to accommodate removal of simulant during the addition of formic acid. Three formated samples for each tests were obtained. This provided a continuum (as defined by three points) for the glass redox values as a function of formic acid addition amount at a given initial carbonate and nitrate feed concentration.

2. The amount of formic added was based on the initial target nitrate molarity rather than the neutralization reactions.

\subsection{TEST SIMULANT PREPARATION}

A $20 \mathrm{~L}$ batch of test simulant was prepared via precipitation of hydroxide salts from dissoived nitrate salts. Four major constituents ( $\mathrm{Ni}, \mathrm{Fe}$, $\mathrm{Al}$, and $\mathrm{Zr}$ ) were precipitated separately. The remaining minor constituents were co-precipitated or added as insoluble salts. The precipitated hydroxide salts were washed and filtered to remove excess sodium and nitrate. The sodium and nitrate concentration prior to adjustment was 5 and $8 \mathrm{~g} / \mathrm{L}$, respeciively. The precipitated hydroxide saits were blended and aged for a minimum of 2 weeks prior to commencement of testing.

Individual $1.5 \mathrm{~L}$ aliquots were removed from the stock batch and spiked with sodium bicarbonate and/or sodium nitrate as prescribed by the test matrix. When required, additional sodium was added as sodium hydroxide to satisfy sodium target values. The simulant target composition is shown in Table 4.2.

\subsection{FORMATING AND VITRIFICATION PROCEDURE}

After adjustment of the carbonate and nitrate concentrations, the simulant was heated to $95 \pm 3^{\circ} \mathrm{C}$ and maintained at this temperature for 10 minutes. Formic acid (90 wt\%) was added to the simulant at a rate of 
TABLE 4.2. Simulant Target Composition(a)

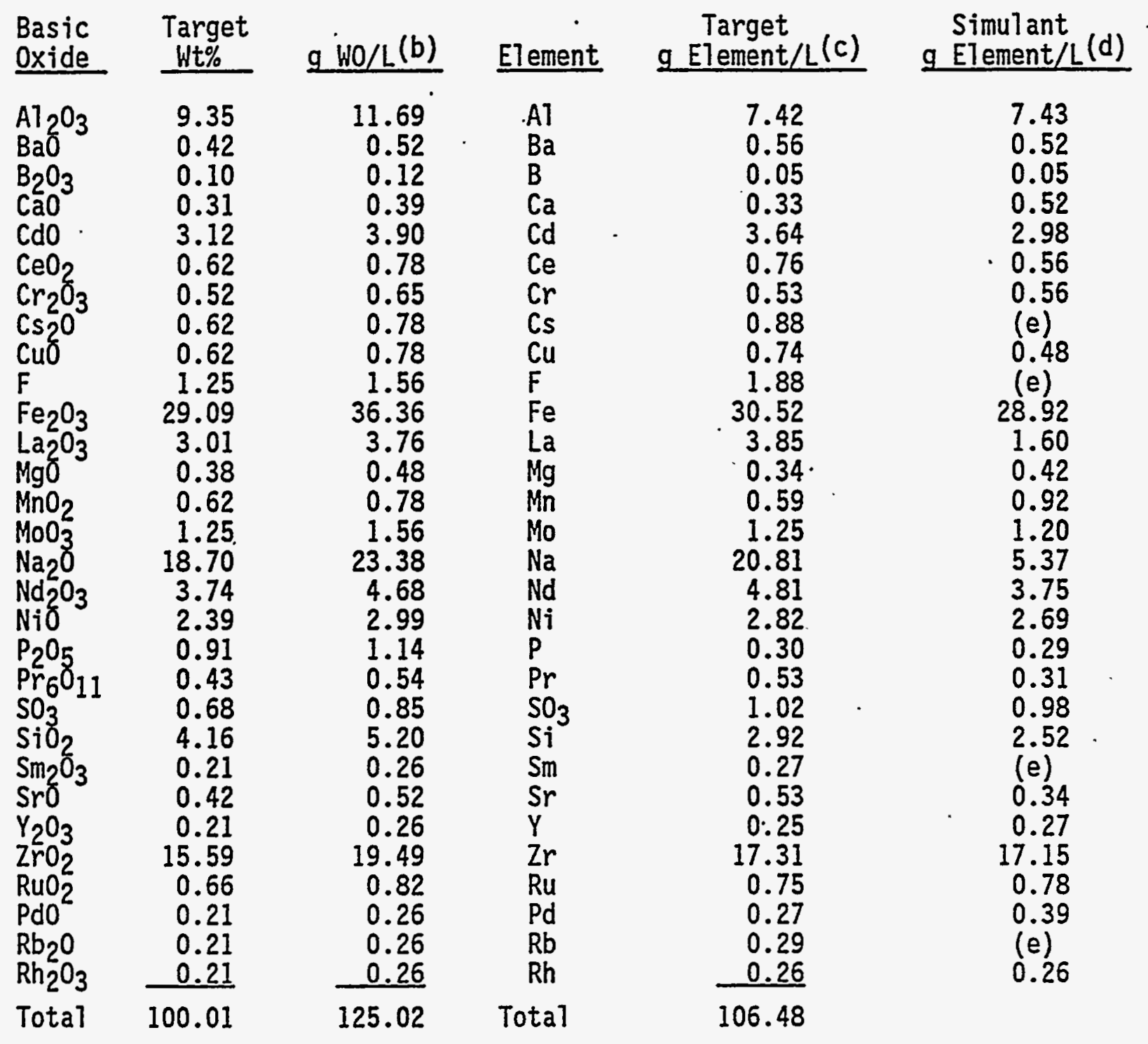
(a) The wt\% values vary slightly from values given in Wright (1988) due
to substitution/deletion of selected oxides and renormalization of composition.

(b) Per Test PTan HWVP-89-1VJ0010300A, based on $125 \mathrm{gWO} / \mathrm{L}$.

(c) Per Test PIan HNYP-89-1VJ0010300A, based on $150 \mathrm{gWO} / \mathrm{L}$.

(d) Sodium Tevel adjusted by addition of $\mathrm{NaNO}_{3}, \mathrm{NaHCO}_{3}$, and/or $\mathrm{NaOH}$.

(e) Fluoride data was not reproducible. $\mathrm{P}, \mathrm{Pr}, \mathrm{Pd}$, and $\mathrm{Rh}$ measurements were not analyzed by approved impact level II procedures, and are listed for information only. CS and $\mathrm{Rb}$ not measured. 
- $1 \mathrm{ml} / \mathrm{min}$ : At the completion of formic acid addition, the formated simulant was refluxed at $95 \pm 3^{\circ} \mathrm{C}$ for $2 \mathrm{hrs}$. The reflux period was provided to allow for completion of reactions with formic acid. The simulant was continuousty agitated with a propeller type blade. The feed $\mathrm{pH}$ and temperature were monitored throughout the heating, formating, and reflux steps. These steps simulated those currently $\mathrm{planned}$ for HWVP operation.

Runs 11-13 simulant samples were collected during formic acid addition by removing the $\mathrm{pH}$ electrode and siphoning the simulant into a tared vessel. The receiving vessel was weighed, the sample volume marked, and the vessel placed into a heating mantle to reflux the sample for two hours at $95 \pm 3^{\circ} \mathrm{C}$.

A $500 \pm 50 \mathrm{~g}$ total oxide (TO)/L simulant was prepared by the addition of frit (weight ratio of waste oxide to frit oxide being 125/375). An aliquot of the formated simulant + frit was vitrified by stepwise additions of an aliquot of the mixture to a crucible. The crucible and its contents were heated to $1000^{\circ} \mathrm{C}$ in a muffle furnace between additions. The $\mathrm{Fe}^{+2} / \mathrm{Fe}^{+3}$ ratio was determined spectrophotometrically.

\subsection{ANALYTICAL TESTS}

The test simulant composition was characterized using ion chromatography (IC) for sulfate and nitrate; specific ion electrode for fluoride ion; and inductively coupled plasma spectroscopy (ICP) for the metallic elements. The sludge and supernate fractions of the slurry were anciyzed independentiy to determine the total inorganic and organic carbon in Runs I-10 anc by ICP and IC for Runs 12 and 13.

The following physical and rheological properties of Runs 1-10 simulants were measured: yield stress, apparent viscosity as a function of shear rate, wit\% total oxides, wt\% total solids, gTO/L feed, $\mathrm{pH}$, density, and settling rate.

Similar analyses were performed for Runs 11-13, with the exception that the rheological properties, settiing rate, and carbon concentration were not determined. 


\subsection{EOUIPMENT DESCRIPTION}

The formating apparatus consisted of a $2 \mathrm{~L}$ glass kettle placed in a temperature controlled heating mantle. The kettle lid was modified to accept a simulant thermocouple, formic acid addition tube, $\mathrm{pH}$ electrode and automatic temperature compensator, an agitator shaft, and condenser. The formic acid was introduced into the kettle below the simulant surface through a teflon tube using a peristaltic pump to control the addition rate. Both simulant temperature and $\mathrm{pH}$ were monitored during the process. A schematic of the simulant formating apparatus is shown in Figure 5.1 .

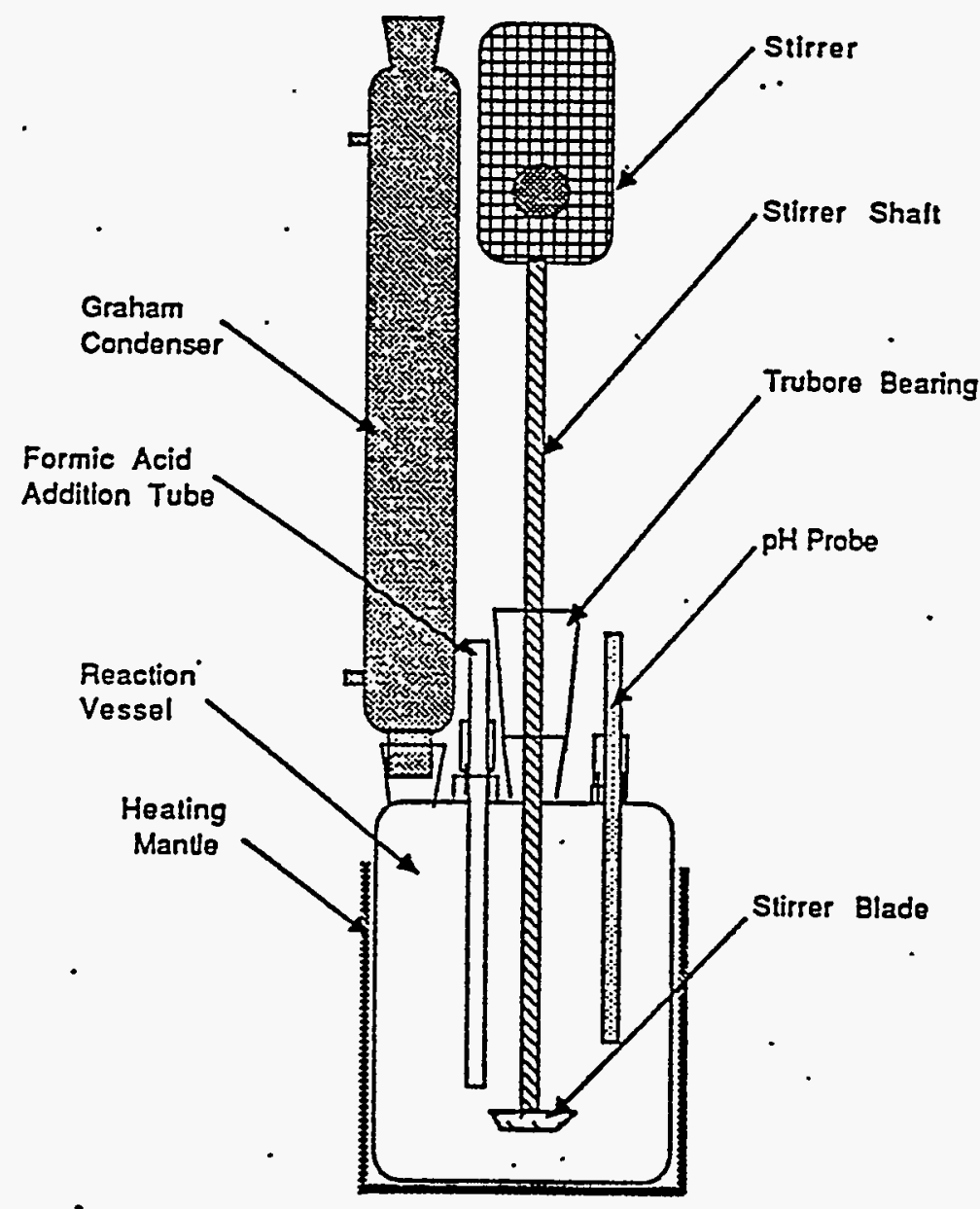

FIGURE 5.1. Schematic of the Formating Apparatus 


\subsection{HIGHLIGHTS}

Observations recorded in addition to measurements specified in the Test Plan are discussed. These include the detection of ammonia and magnetic particles in the formated simulant and the apparent dilatant behavior of a melter feed simulant.

The presence of ammonia was qualitatively detected in Runs 1-11 and 13 formated simulant. All of these runs had an alkaline post reflux $\mathrm{pH}$; the ammonia therefore being presence primarity as, the easily detectable $\mathrm{NH}_{3}$ species. Run 12, Sample 3 was the only sample with a post reflux $\mathrm{pH}<7$. If ammoria was present it would be as the ammonium ion, $\mathrm{NH}_{4}^{+}$ion, and not detected by odor. When base $(\mathrm{NaOH})$ was added to make Run 12 , sample 3 alkaline, $\mathrm{NH}_{3}$ was detected also. This observation suggested an alternative route for the nitrate reduction step.

During Run 12, when the adjustment of low oxide content by evaporation. in sample 2 was carried out by use of a heating plate and stir bar instead of in a furnace, magnetic particles in the formated feed were observed clinging to the stir bar. Magnetic particles were subsequently identified by use of a hand held magnet, in sample 1 , and all vitrified samples. The feed (prior to formic acid addition) and Sample 3 (151 $\mathrm{ml} 90 \mathrm{wt} \%$ formic acid/L) did not contain a detectable amount of magnetic particles. The crystalline composition of the magnetic particies from the formated simulant (prior to vitrification) wias determined by $X$-ray diffraction to be a combination of the following phases: ( $\mathrm{NiFe}) \mathrm{Fe}_{2} \mathrm{O}_{4}, \mathrm{NiFe}_{2} \mathrm{O}_{4}, \mathrm{Fe}_{2} \mathrm{O}_{3}, \mathrm{FeO}(\mathrm{OH})$, and $\mathrm{Fe}_{3} \mathrm{O}_{4}$. The existence of these particles will require further consideration should the presence of a magnetic field be identified in subsequent process steps.

The maximum amount of formic acid added in this study was $151 \mathrm{ml} 90 \mathrm{wt} \%$ formic acid/L. The rheological behavior of the melter feed prepared by the addition of frit to this formated sample was not quantified. However, the material appeared to be dilatant. The surface of the material was shiny and moist-like in a static condition. When stirred, the surface became dull, and the resistance to flow increased greatly. This behavior was not observed at a loading of $90 \mathrm{ml} 90 \mathrm{wt} \%$ formic acid/L. Using the formic acid requirement 
criteria of $\mathrm{HCOOH} / \mathrm{NO}_{3}=3$, the maximum amount of formic acid required for maximum nitrate loadings would approach the formic acid loading in which the dilatant behavior was observed. The addition of sugar as a reductant to reduce the amount of formic acid required may resolve this potential problem. However, the rheology of the feed with formic acid and sugar should be measured. 


\subsection{RESSULTS}

The simulant composition and physical data are presented and compared with previous studies. Neutralization and redox chemistry are related to the observed solubility behavior and glass redox state. A preliminary mass balance for redox reactions which take place during formating and vitrification is described.

\subsection{SIMULANT COMPOSITION}

Table 7.1 7ists the actual and target compositions of the simulants for Runs 1-10. The four major components on a weight percent basis, $\mathrm{Fe}, \mathrm{Na}, \mathrm{Al}$, and $\mathrm{Zr}$, are within $10 \%$ of the target concentrations. Deviations in minor constituent composition are similar to those reported for past simulants (Wiemers 1987): Differential losses may be due to the extraction of more soluble species during washing and nonrepresentative sampling of minor, insoluble salts such as lanthanum fluoride. The carbon analytical data was suspect due to contamination of the instrument detector. In runs where carbonate additions were made target compositional values were assumed for evaluation of tests results.

The compositions of the formated simulants for Runs 1-10 are listed in Table 7.2. Compositional data for Run II is 7isted in Table 7.3. A.s expected no significant differences in the individual component concentration exists between the initial simulant and formated simulant except for nitrate. The decrease in nitrate concentration with addition of formic acid can be explained by the reduction of the nitrate to gaseous products, $\mathrm{NO}_{x}, \mathrm{~N}_{2} \mathrm{O}$, and ammonia. SRL (Zamecnik) has reported a recycle of the nitrate in their pilot scale operations via the following disproportionation and decomposition reactions in the condenser:

$$
\begin{gathered}
\mathrm{NO}+\mathrm{I} / 2 \mathrm{O}_{2} \rightarrow \mathrm{NO}_{2} \\
2 \mathrm{NO}_{2}+\mathrm{H}_{2} \mathrm{O} \rightarrow \mathrm{HNO}_{3}+\mathrm{HNO}_{2} \\
3 \mathrm{HNO}_{2} \rightarrow \mathrm{HNO}_{3}+2 \mathrm{NO}+\mathrm{H}_{2} \mathrm{O}
\end{gathered}
$$


IABLE 7.1. Composition of Simulant for Runs $1-10, \mathrm{~g} / \mathrm{L}$

\begin{tabular}{|c|c|c|c|c|c|c|c|c|c|c|c|c|c|c|c|}
\hline & Element ${ }^{(a)}$ & $\begin{array}{c}\text { Run } \\
1\end{array}$ & $\begin{array}{c}\text { Run } \\
2 \\
\end{array}$ & $\begin{array}{c}\text { Run } \\
3\end{array}$ & $\begin{array}{c}\text { Run } \\
4 \\
\end{array}$ & $\begin{array}{c}\text { Run } \\
5 \\
\end{array}$ & $\begin{array}{c}\text { Run } \\
6 \\
\end{array}$ & $\begin{array}{c}\text { Run } \\
7 \\
\end{array}$ & $\begin{array}{c}\text { Run } \\
8 \\
\end{array}$ & $\begin{array}{c}\text { Run } \\
9\end{array}$ & $\begin{array}{l}\text { Run } \\
10 \\
\end{array}$ & $\begin{array}{c}\text { Runs } \\
1-10 \\
\text { Average }\end{array}$ & $\begin{array}{l}\text { Percent } \\
\text { RSO } \\
\end{array}$ & Target & $\begin{array}{c}\text { Average } \\
\text { Runs } 1-10 \\
\text { Percent } \\
\text { Deviation }\end{array}$ \\
\hline$i$ & $\begin{array}{l}\mathrm{Al} \\
\mathrm{B} \\
\mathrm{Ba} \\
\mathrm{Ca} \\
\mathrm{Cd} \\
\mathrm{Ce} \\
\mathrm{Cr} \\
\mathrm{Cu} \\
\mathrm{Fe} \\
\mathrm{La} \\
\mathrm{Mg} \\
\mathrm{Mn} \\
\mathrm{Ho} \\
\mathrm{Na} \\
\mathrm{Nd} \\
\mathrm{Hi} \\
\mathrm{RU} \\
\mathrm{SO} \\
\mathrm{Si} \\
\mathrm{Sr} \\
\mathrm{Y} \\
\mathrm{Zr} \\
\mathrm{NO3} \\
\mathrm{CO3}(\mathrm{C})\end{array}$ & $\begin{array}{r}7.23 \\
0.04 \\
0.51 \\
0.53 \\
2.93 \\
0.57 \\
0.51 \\
0.47 \\
27.74 \\
1.10 \\
0.42 \\
0.91 \\
1.19 \\
19.76 \\
3.64 \\
2.62 \\
0.76 \\
1.57 \\
2.48 \\
0.34 \\
0.27 \\
17.41 \\
28.5 \\
21\end{array}$ & $\begin{array}{c}6.94 \\
0.05 \\
0.49 \\
0.50 \\
2.82 \\
0.61 \\
0.54 \\
0.43 \\
28.17 \\
1.43 \\
0.39 \\
0.87 \\
1.19 \\
25.42 \\
3.74 \\
2.59 \\
0.71 \\
1.15 \\
2.74 \\
0.32 \\
0.23 \\
16.03 \\
45.8 \\
21\end{array}$ & $\begin{array}{r}7.24 \\
0.04 \\
0.49 \\
0.50 \\
2.80 \\
0.58 \\
0.54 \\
0.41 \\
27.07 \\
1.06 \\
0.38 \\
0.85 \\
1.16 \\
18.72 \\
3.54 \\
2.71 \\
0.71 \\
1.02 \\
2.48 \\
0.33 \\
0.25 \\
15.79 \\
8.01 \\
3\end{array}$ & $\begin{array}{l}6.85 \\
0.26 \\
0.48 \\
0.54 \\
2.79 \\
0.72 \\
0.53 \\
0.12 \\
27.50 \\
1.27 \\
0.39 \\
0.86 \\
1.14 \\
23.67 \\
3.64 \\
2.52 \\
0.66 \\
1.01 \\
2.61 \\
0.32 \\
0.23 \\
15.89 \\
42.8 \\
21\end{array}$ & $\begin{array}{r}7.21 \\
0.04 \\
0.50 \\
0.54 \\
2.87 \\
0.59 \\
0.55 \\
0.46 \\
27.44 \\
1.30 \\
0.41 \\
0.87 \\
1.15 \\
19.49 \\
3.63 \\
2.52 \\
0.62 \\
1.01 \\
2.37 \\
0.33 \\
0.26 \\
16.91 \\
7.73 \\
38\end{array}$ & $\begin{array}{r}7.39 \\
0.05 \\
0.51 \\
0.55 \\
2.92 \\
0.57 \\
0.57 \\
0.46 \\
27.92 \\
1.28 \\
0.41 \\
0.90 \\
1.20 \\
18.92 \\
3.60 \\
2.59 \\
0.69 \\
1.01 \\
2.59 \\
.0 .34 \\
0.26 \\
16.89 \\
7.77 \\
38\end{array}$ & $\begin{array}{c}6.87 \\
0.19 \\
0.49 \\
0.51 \\
2.88 \\
0.66 \\
0.54 \\
0.43 \\
27.96 \\
1.65 \\
0.40 \\
0.87 \\
1.20 \\
24.00 \\
3.75 . \\
3.21 \\
0.79 \\
1.13 \\
2.49 \\
0.32 \\
0.24 \\
16.30 \\
54.3 \\
3\end{array}$ & $\begin{array}{r}7.49 \\
0.06 \\
0.52 \\
0.58 \\
2.95 \\
0.61 \\
0.57 \\
0.48 \\
28.39 \\
1.43 \\
0.43 \\
0.90 \\
1.23 \\
20.70 \\
3.78 \\
2.69 \\
0.68 \\
1.13 \\
2.70 \\
0.34 \\
0.26 \\
17.87 \\
8.26 \\
3\end{array}$ & $\begin{array}{c}6.97 \\
0.08 \\
0.50 \\
0.55 \\
2.95 \\
0.69 \\
0.57 \\
0.44 \\
28.78 \\
1.67 \\
0.40 \\
0.88 \\
1.23 \\
23.53 \\
3.80 \\
2.57 \\
0.80 \\
1.14 \\
2.51 \\
0.33 \\
0.24 \\
16.56 \\
53.7 \\
3\end{array}$ & $\begin{array}{c}7.08 \\
0.05 \\
0.50 \\
0.54 \\
2.90 \\
0.66 \\
0.56 \\
0.43 \\
20.63 \\
1.51 \\
0.39 \\
0.89 \\
1.14 \\
18.03 \\
3.81 \\
2.60 \\
0.77 \\
1.13 \\
2.52 \\
0.32 \\
0.24 \\
16.34 \\
20.3 \\
21\end{array}$ & $\begin{array}{c}7.13 \\
0.09 \\
0.50 \\
0.53 \\
2.88 \\
0.63 \\
0.55 \\
0.45 \\
27.96 \\
1.37 \\
0.40 \\
0.88 \\
1.18 \\
21.22 \\
3.69 \\
2.66 \\
0.72 \\
1.26 \\
2.55 \\
0.33 \\
0.25 \\
16.60 \\
N / A(b) \\
N / A\end{array}$ & $\begin{array}{r}3.08 \\
87.21 \\
2.17 \\
4.80 \\
2.07 \\
8.49 \\
2.89 \\
4.77 \\
1.94 \\
15.10 \\
3.60 \\
2.23 \\
2.98 \\
12.54 \\
2.54 \\
7.61 \\
8.28 \\
0.45 \\
4.33 \\
2.36 \\
4.69 \\
4.06 \\
N / A \\
N / A\end{array}$ & $\begin{array}{c}7.42 \\
0.05 \\
0.56 \\
0.33 \\
3.64 \\
0.76 \\
0.53 \\
0.74 \\
30.52 \\
3.85 \\
0.34 \\
0.59 \\
1.25 \\
20.81 \\
4.81 \\
2.82 \\
0.75 \\
1.02 \\
2.92 \\
0.53 \\
0.25 \\
17.31 \\
\text { N/A } \\
\text { N/A }\end{array}$ & $\begin{array}{r}3.95 \\
-73.81 \\
11.19 \\
-61.79 \\
20.90 \\
17.69 \\
-4.12 \\
39.73 \\
8.39 \\
64.41 \\
-17.98 \\
-49.07 \\
5.25 . \\
-1.99 \\
23.22 \\
5.58 \\
4.15 \\
0.24 \\
12.64 \\
37.73 \\
0.80 \\
4.11 \\
\text { N/A } \\
\text { N/A }\end{array}$ \\
\hline
\end{tabular}

(a) Fluoride datn was not reproducible. $\mathrm{P}, \mathrm{Pr}, \mathrm{Pd}$, and $\mathrm{Rh}$ measurements were not analyzed by approved impact level II procedures, and are listed for information only. Cs and $R b$ not measured.

(b) Not applicable.

(c) Values listed for Runs 1, 2, 4, 5, 6, and 10 are based on' the amount of $\cos$ added. Values for Runs 3, 7, 8, and 9 represent carbonate derived from equilibrium with room air and may include carbonate contaminants from chemicals used to prepare the simulant. The, carbonate value listed for these tests is based on analytical data averaged over these four tests. The analytical data may be in error by as much as $50 \%$. 
TABLE 7.2. Conposition of Formated Simulant for Runs 1-10, g/L

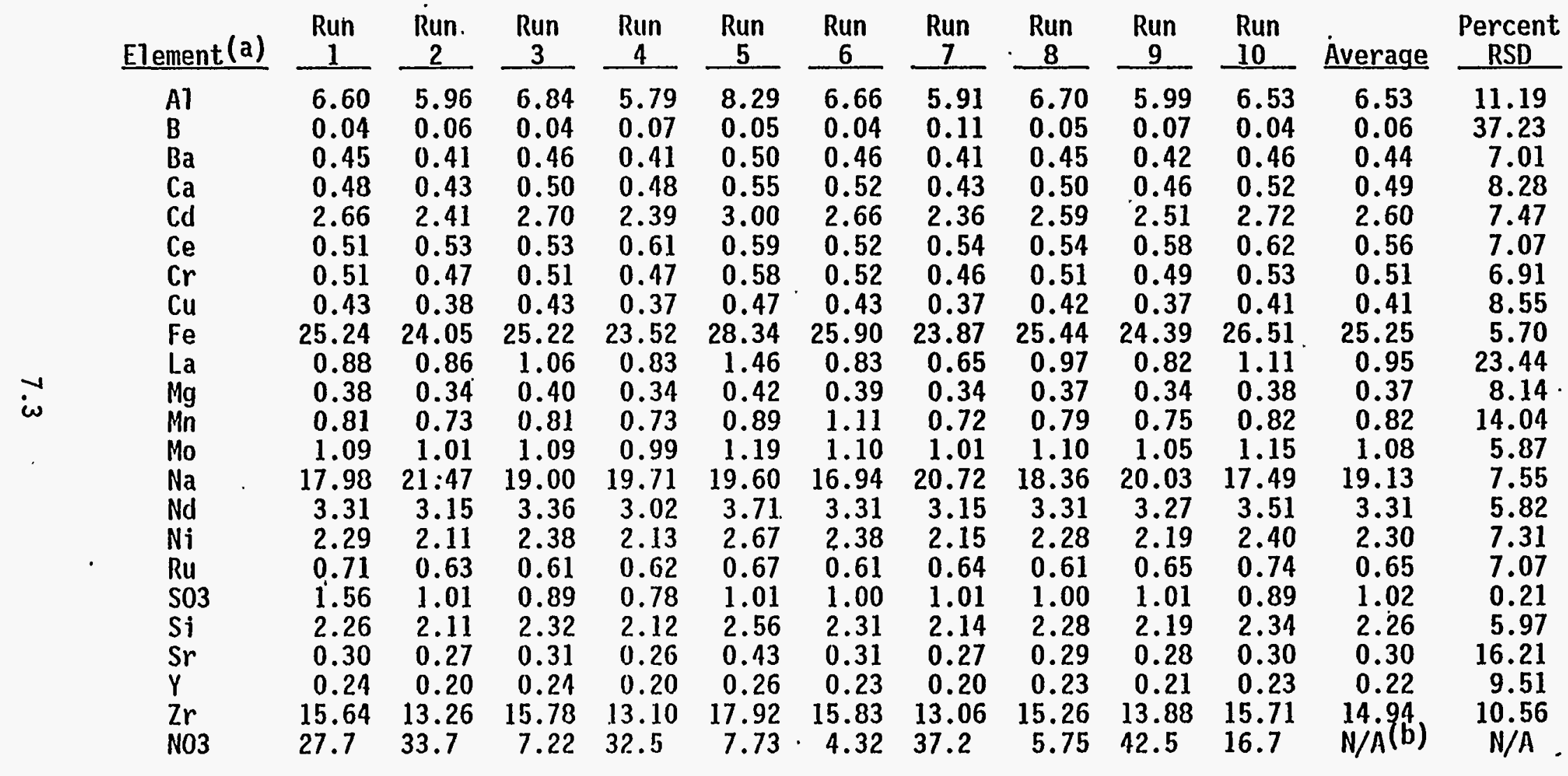

(a) Fluoride dalia was not reproducible. $\mathrm{P}, \mathrm{Pr}, \mathrm{Pd}$, and $\mathrm{Rh}$ measurements were not analyzed by approved impact level II procedures, and are listed for information only. Cs and Rb not measured.

(b) Not applicable. 
TABLE 7.3. Run 11 Compositional Datâ, $g / L^{(a)}$

\begin{tabular}{|c|c|c|c|c|c|}
\hline Element & Target & $\begin{array}{c}\text { Preformate } \\
\text { Feed } \\
\end{array}$ & $\begin{array}{c}23 \mathrm{ml} \cdot \text { Formic } \\
\mathrm{acid} / \mathrm{L}\end{array}$ & $\begin{array}{c}32 \mathrm{ml} \text { Formic } \\
\mathrm{acid} / \mathrm{L}\end{array}$ & $\begin{array}{c}53 \mathrm{~m} 7 \text { Formic } \\
\mathrm{acid} / \mathrm{L}\end{array}$ \\
\hline Al & 7.42 & 6.41 & 7.30 & 5.97 & 6.56 \\
\hline $\mathrm{Ba}$ & 0.56 & 0.48 & 0.54 & 0.44 & 0.08 \\
\hline B & 0.05 & 0.07 & 0.08 & 0.06 & 0.48 \\
\hline $\mathrm{Ca}$ & 0.33 & 0.50 & 0.55 & 0.46 & 0.50 \\
\hline $\mathrm{Cd}$ & 3.64 & 2.76 & 3.10 & 2.54 & 2.73 \\
\hline $\mathrm{Ce}$ & 0.76 & 0.74 & 0.81 & 0.64 & 0.71 \\
\hline $\mathrm{Cr}$ & 0.53 & 0.50 & 0.58 & 0.47 & 0.53 \\
\hline $\mathrm{Cu}$ & 0.74 & 0.43 & 0.47 & 0.39 & $0.43^{\circ}$ \\
\hline $\mathrm{Fe}$ & 30.52 & 27.26 & 30.91 & .25 .31 & 27.5 \\
\hline La & 3.85 & 1.35 & 0.94 & 0.93 & 1.50 \\
\hline $\mathrm{Mg}$ & 0.34 & 0.43 & 0.48 & 0.40 & 0.43 \\
\hline Mn & 0.59 & 0.84 & 0.94 & 0.77 & 0.84 \\
\hline Mo & 1.25 & 1.12 & 1.29 & 1.06 & 1.14 \\
\hline $\mathrm{Na}$ & 20.81 & 22.17 & 25.54 & 21.06 & 22.5 \\
\hline $\mathrm{Nd}$ & 4.81 & 3.69 & 4.13 & 3.40 & 3.68 \\
\hline $\mathrm{Ni}$ & 2.82 & 2.49 & 2.67 & 2.23 & 2.43 \\
\hline$P$ & 0.30 & 0.37 & 0.40 & 0.31 & 0.51 \\
\hline $\mathrm{SO}_{4}$ & 1.02 & 1.21 & 1.34 & 0.87 & 1.05 \\
\hline Si & 2.92 & 0.49 & 0.58 & 0.43 & 0.63 \\
\hline$s r$ & 0.53 & 0.32 & 0.36 & 0.29 & 0.32 \\
\hline$Y$ & 0.25 & 0.23 & 0.26 & 0.21 & 0.23 \\
\hline $\mathrm{Zr}$ & 17.31 & 15.04 & 17.14 & 14.00 & 15.4 \\
\hline $\mathrm{NO}_{3}$ & & 22 & 15 & 13 & 5.5 \\
\hline
\end{tabular}

(a) Fluoride data was not reproducible. $\mathrm{CO}_{3}, \mathrm{Cs}, \mathrm{P}, \mathrm{Pr}, \mathrm{Sm}, \mathrm{Pd}, \mathrm{Rb}$, and Rh not measured.

It is not certain whether this scenario would occur during laboratory scale formating.

Similar trends in composition were observed for Runs 12 and 13 . Compositional data for Runs 12 and 13 are discussed further in Section 7.4. 


\subsection{PHYSIICAL CHARACTERISTICS}

The physical characterization of the test_simulant includes $\mathrm{pH}$, rheology, density, wt\% oxide, wt\% solids, and settling rate. The physical properties observed are compared with those reported for previous simulants. other than for $\mathrm{pH}$, no significant trends in the physical properties related to carbonate or nitrate loadings were observed.

\subsection{1 pH Data}

The endpoint $\mathrm{pH}$ after equivalent formic acid addition was more alkaline with higher carbonate content. This is attributed to the high buffering capacity of the carbonate system. During the addition of formic acid, the $\mathrm{pH}$ decreased to a minimum of 5-6 in the presence of added carbonate. A minimum $\mathrm{pH}$ of 3-4 was observed for low carbonate and the maximum amount of formic acid added. During reflux the $\mathrm{pH}$ increased. The $\mathrm{pH}$ after reflux for Run 12 in which an excessive amount of formic acid was added, $151 \mathrm{ml} / \mathrm{L}$ increased only slightly to 4.2. For all other runs the $\mathrm{pH}$ increased to approximately 7-9 after reflux. Acceptable reproducibility between runs for the $\mathrm{pH}$ behavior was demonstrated by replicate Runs 1 and 10 (refer to Figure 7.1).

Two runs in the parametric test, numbers 6 and 8 , resulted in an acceptable redox value $\left(\mathrm{Fe}^{+2} / \mathrm{Fe}^{+3}=0.08\right)$. Runs 6 and 8 had low nitrate loadings, the maximum amount of formic acid added, and high and low concentrations of carbonate, respectiveiy. The pli variation (i.e., carbonate content) for these two runs (difierence of $2 \mathrm{pH}$ units) did not efiect the glass redox value.

\subsubsection{Rheoloay}

Rheograms were obtained for Runs 1-10 preformate and formated (prior to frit addition) simulant. Tables 7.4, 7.5, and 7.6 7ist the fow index, $n$, the consistency factor, $K$, yield stress ( $\left(T a u_{y}\right.$ ), and the apparent viscosity at selected shear rates for initial and formated simulants. Figure 7.2 shows fitted curves of the apparent viscosity as a function of shear rate. The apparent viscosities for Runs 1-10 were averaged at each shear rate for each curve. Rheological measurements for Runs 11-13 were not taken. 


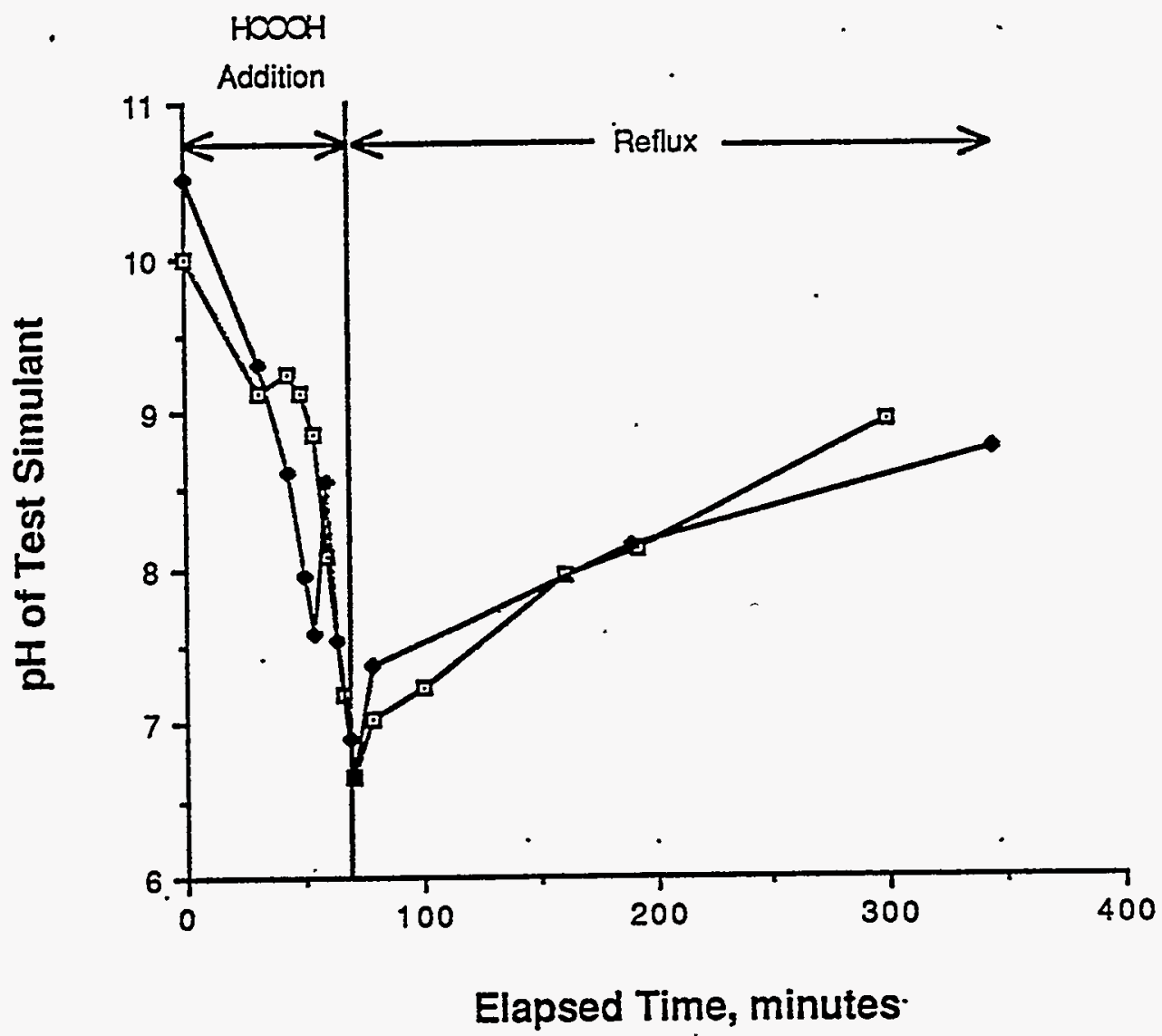

FIGURE 7.1. pH Change During Formic Acid Addition for Runs 1 and 10

The initial simulant exhibited a slight hysteresis (time dependency). Therefore, the apparent viscosity ${ }^{(a)}$ for these samples was calculated for both the up and down curves. The apparent viscosity for the initial simulant

(a) The apparent viscosity was caiculated based on the following relationship:

apparent viscosity $=$ tau/shear rate, $\mathrm{Pa} \cdot \mathrm{Sec}^{-1}$

where $\mathrm{Tau}=\mathrm{Tau}_{\mathrm{y}}+\mathrm{K}$ (shear rate $)^{\mathrm{n}}, \mathrm{Pa}$

$\mathrm{Tau}_{\mathrm{y}}=$ yield stress, $\mathrm{Pa}$

$\mathrm{n}=$ flow index, dimensiontess

$\mathrm{K}=$ consistency factor, $\mathrm{Pa}-\mathrm{Sec}$

A plot of the $\log$ of shear stress versus $\log$ of shear rate defines the values of $n$ and $K$; $n$ being the slope of the line and $K$ being the $y$-intercept. A $n$ value $<1$ indicates pseudoplastic behavior. For Newtonian fluids $n=1$. Shear stress and shear rate are taken from the rheograms. 
TABLE 7.4. Rheology Measurements for Simulant Up Curve

\begin{tabular}{|c|c|c|c|c|c|c|c|c|c|c|c|}
\hline & Run 1 & Run 2 & Run 3 & Run 4 & Run 5 & Run 6 & Run 7 & Run 8 & Run 9 & Run 10 & $\begin{array}{l}\text { PSCH- } \\
23(a)\end{array}$ \\
\hline $\begin{array}{l}\mathbf{n} \\
\text { K } \\
\text { Tauy, }\end{array}$ & $\begin{array}{l}0.806 \\
0.025 \\
1.401\end{array}$ & $\begin{array}{l}0.724 \\
0.042 \\
1.642\end{array}$ & $\begin{array}{l}0.860 \\
0.014 \\
0.918\end{array}$ & $\begin{array}{l}0.865 \\
0.019 \\
1.546\end{array}$ & $\begin{array}{l}0.929 \\
0.010 \\
1.497\end{array}$ & $\begin{array}{l}0.852 \\
0.019 \\
1.594\end{array}$ & $\begin{array}{l}0.839 \\
0.019 \\
2.174\end{array}$ & $\begin{array}{l}0.839 \\
0.016 \\
1.401\end{array}$ & $\begin{array}{l}0.801 \\
0.024 \\
1.835\end{array}$ & $\begin{array}{l}0.833 \\
0.021 \\
1.449\end{array}$ & $3.2^{--}-$ \\
\hline \multicolumn{12}{|c|}{ Apparent Viscosity, cP } \\
\hline $\begin{array}{l}183 \text { sec-1 } \\
383 \text { sec-1 } \\
468 \text { sec-1 }\end{array}$ & $\begin{array}{l}16.856 \\
11.630 \\
10.66\end{array}$ & $\begin{array}{l}18.840 \\
12.336 \\
11.829\end{array}$ & $\begin{array}{r}11.652 \\
8.379 \\
7.778\end{array}$ & $\begin{array}{l}17.603 \\
12.322 \\
12.031\end{array}$ & $\begin{array}{r}15.375 \\
10.737 \\
9.931\end{array}$ & $\begin{array}{l}17.331 \\
11.892 \\
10.911\end{array}$ & $\begin{array}{l}20.280 \\
13.137 \\
12.803\end{array}$ & $\begin{array}{r}14.619 \\
9.841 \\
8.980\end{array}$ & $\begin{array}{l}18.396 \\
12.013 \\
10.860\end{array}$ & $\begin{array}{l}16.557 \\
11.421 \\
10.482\end{array}$ & $\begin{array}{l}31-34 \\
20-22 \\
18-20\end{array}$ \\
\hline
\end{tabular}

(a) Goles and Nakaoka 1989.

IABLE 7.5. Rheology Measurements for Simulant Down Curve

\begin{tabular}{|c|c|c|c|c|c|c|c|c|c|c|}
\hline & Run 1 & Run 2 & n 3 & & $\ln 5$ & un 6 & Sun 7 & Run 8 & Run 9 & Run \\
\hline $\begin{array}{l}n \\
K \\
K\end{array}$ & $\begin{array}{l}0.845 \\
0.021 \\
0.918\end{array}$ & $\begin{array}{l}0.838 \\
0.023 \\
1.076\end{array}$ & & & & & & & & \\
\hline & & & & & & & & & & \\
\hline \multicolumn{11}{|c|}{ Apparent Viscosity, CP } \\
\hline $\begin{array}{ll}183 & \text { sec-1 } \\
383 & \text { sec-1 } \\
468 & \text { sec-1 }\end{array}$ & $\begin{array}{l}14.540 \\
10.890 \\
10.194\end{array}$ & $\begin{array}{l}16.758 \\
12.012 \\
11.130\end{array}$ & $\begin{array}{l}9.555 \\
7: 520 \\
7.114\end{array}$ & $\begin{array}{l}15.667 \\
11.459 \\
10.668\end{array}$ & $\begin{array}{r}11.674 \\
9.655 \\
9.260\end{array}$ & $\begin{array}{l}15.284 \\
11.191 \\
10.420\end{array}$ & $\begin{array}{l}17.655 \\
12.508 \\
11.565\end{array}$ & $\begin{array}{r}11.246 \\
8.704 \\
8.215\end{array}$ & & $\begin{array}{l}14.740 \\
10.774 \\
10.006\end{array}$ \\
\hline
\end{tabular}


TABLE 7.6. Rheology Measurements for Formated Simulant

Run 1 Run 2 Run 3 Run 4 Run 5 Run 6 Run 7 Run 8 Run 9 Run 10

PSCM-
$23(a)$

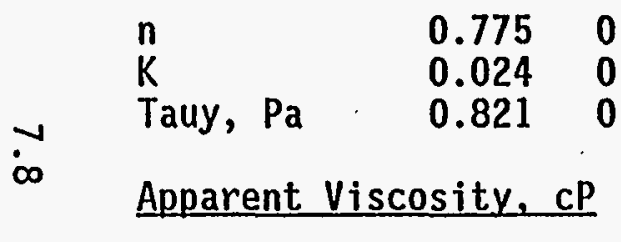

183 sec-1 11.761

383 sec-1

8.302

8.121

0.905

0.793

0.864

0.858

0.853

0.799

0.780

0.787

0.011

0.821

0.531

0.966

0.725

0.011

0.016

0.018

0.022

--

$\begin{array}{llll}0.435 & 0.580 & 0.580 & 0.869\end{array}$

2.7

468 sec-1

$7.641 \quad 6.037$

9.591
6.901

8.780

$13.611 \quad 10.884$

6.432

10.057

10.884
8.129

7.513

8.879

6.438

$\begin{array}{rr}8.922 & 12.117 \\ 6.403 & 8.562 \\ 5.917 & 7.886\end{array}$

29

5.404

5.969

20

(a) Goles and Nakaoka 1989. 


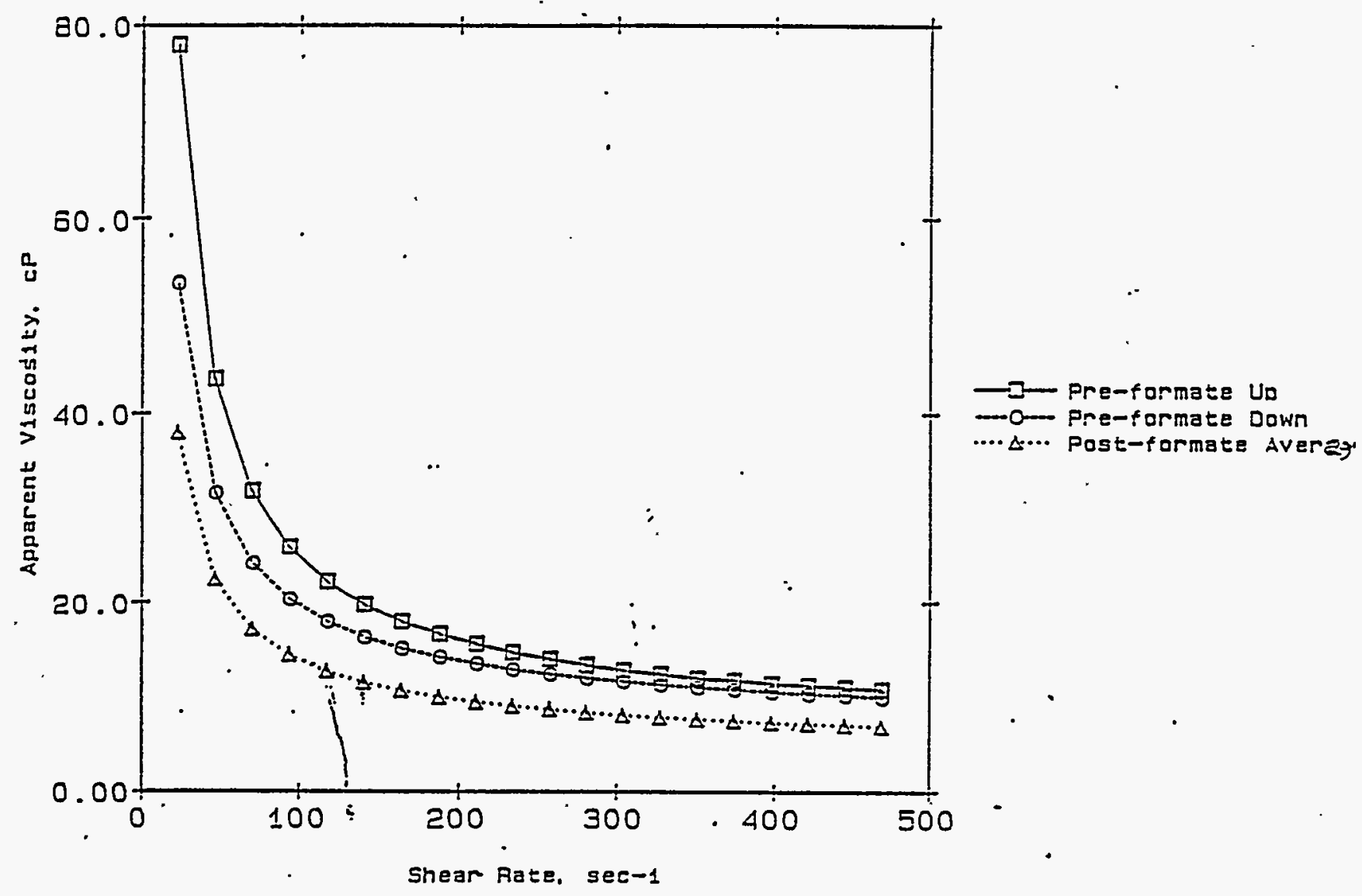

FIGURE 7.2. Comparison of Apparent Viscosity as a Function of Shear Rate for Initial and Formated Simulants

ranged from 20 to 7 centipoise $(C P)$ in the shear rate range of 183 to 468 $\mathrm{sec}^{-1}$. The yield stress ranged from 0.435 to $2.17 \mathrm{~Pa}$. The apparent viscosity decreased after formic acid addition, ranging from $13: 6$ to $5.4 \mathrm{cP}$ in the shear rate range of 183 to $468 \mathrm{sec}^{-1}$. The maximum yield stress was lower for formated simulant, the range being from 0.435 to $0.966 \mathrm{~Pa}$.

Rheological properties were fairly consistent over the range of formic acid added $(16-31 \mathrm{ml} / \mathrm{L})$ and nitrate and carbonate contents. The initial and formated simulants' apparent viscosity and yield stress were lower by a factor of 2-3 compared with PSCM-23 data (Goles and Nakaoka 1989).

\subsubsection{Density, \% Total Solids, \% Total Oxide, and Total Oxide/L}

Table 7.7 lists the density, wt\% solids, wt\% To and $\mathrm{g}$ WO/L for each test simulant. The stock feed batch was prepared per column 5, Table C.1 of the 
TABLE 7.7. Physical Properties of Test Simulants(a)

Density Run 1 Run 2 Run 3 Run 4 Run 5 Run 6 Run 7 Run 8 Run 9 Run 10

$\begin{array}{lllllllllll}\text { Preformate } & 1.12 & 1.15 & 1.13 & 1.14 & 1.12 & 1.13 & 1.13 & 1.13 & 1.14 & 1.13 \\ \text { Formated } & 1.12 & 1.12 & 1.11 & 1.12 & 1.12 & 1.11 & 1.13 & 1.11 & 1.12 & 1.11 \\ \text { Frit } & 1.29 & 1.29 & 1.27 & 1.29 & 1.30 & 1.30 & 1.29 & 1.29 & 1.30 & 1.29\end{array}$

Frit

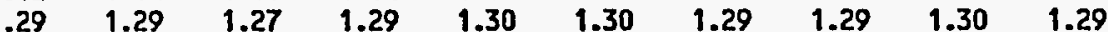

Percent

Total Solids Run 1 Run 2. Run 3 Run 4 Run 5 Run 6 Run 7 Run 8 Run 9 Run 10

$\begin{array}{lllllllllll}\text { Preformate } & 16.20 & 18.13 & 14.65 & 17.95^{\circ} & 15.66 & 15.52 & 17.97 & 14.58 & 18.11 & 16.14\end{array}$

\begin{tabular}{llllllllllll} 
Formated & 16.34 & 17.99 & 15.72 & 17.89 & 15.91 & 15.59 & 17.98 & 15.96 & 18.34 & 16.10 \\
\hline & 14.90 & 15.86 & 14.32 & 15.22 & & 14 & 14.46 & 15.92 & 14.54 & 16.12 & 15.11
\end{tabular}

$\begin{array}{lllllllllll}\text { Adjusted } & 14.90 & 15.86 & 14.32 & 15.22 & \text { (b) } & 14.46 & 15.92 & 14.54 & 16.12 & 15.11 \\ \text { Frit } & 35.77 & 36.43 & 35.31 & 35.36 & 51.20 & 36.64 & 35.91 & 35.06 & 36.84 & 36.08\end{array}$

Percent

Iotal Oxide Run 1 Run 2 Run 3 Run 4 Run 5 Run 6 Run 7 Run 8 Run 9 Run 10

$\begin{array}{llllllllllll}\text { Freformate } & 12.26 & 12.71 & 12.42 & 12.78 & 12.06 & 12.03 & 12.61 & 12.37 & 12.69 & 12.22\end{array}$

$\begin{array}{llllllllllll}\text { Formated } & 12.37 & 12.61 & 12.44 & 12.90 & 12.15 & 12.04 & 12.42 & 12.20 & 12.62 & 12.07\end{array}$

$\begin{array}{lllllllllll}\text { ndjusted } & 11.08 & 11.06 & 11.36 & 10.73 & \text { (b) } & 11.15 & 10.99 & 11.26 & 11.09 & 11.35\end{array}$

$\begin{array}{lllllllllll}\text { frit } & 32.83 & 32.45 & 32.85 & 31.75 & 35.46 & 34.21 & 32.07 & 32.26 & 32.93 & 33.12\end{array}$

Total

Oxidg/L Run 1 Run 2. Run 3 Run 4 Run 5 Run 6 Run 7 Run B Run 9 Run 10

$\begin{array}{llllllllllll}\text { Preformate } & 137.68 & 1 / 45.57 & 140.12 & 145.58 & 135.00 & 135.41 & 142.76 & 139.95 & 144.86 & 137.75\end{array}$

$\begin{array}{llllllllllll}\text { Formated } & 137.58 & 1 / 3.73 & 138.64 & 147.19 & 121.50 & 134.61 & 141.44 & 136.88 & 143.37 & 135.29\end{array}$

$\begin{array}{lllllllllll}\text { ndjusted } & 123.76 & 124.34 & 126.17 & 120.15 & \text { (b) } 123.41 & 123.74 & 124.62 & 124.13 & 126.37\end{array}$

$\begin{array}{lllllllllll}\text { frit. } & 424: 64 & 418.54 & 418.18 & 408.02 & 463.46 & 445.36 & 453.49 & 414.54 & 426.88 & 426.81\end{array}$

\begin{tabular}{|c|c|c|c|c|c|c|c|c|c|c|c|c|}
\hline \multirow[b]{2}{*}{$\begin{array}{l}\mathrm{ml} 90 \mathrm{wt \%} \text { Formic Acid/L. } \\
\text { Density, g/ml } \\
\text { Percent Totnl Solids } \\
\text { Percent Total Oxide } \\
\text { Total Oxide/L. }\end{array}$} & \multicolumn{4}{|c|}{ Run 11} & \multicolumn{4}{|c|}{ Run 12} & \multicolumn{4}{|c|}{ Run 13} \\
\hline & $\begin{array}{c}0 \\
1.13 \\
15.7 \\
11.3 \\
128\end{array}$ & $\begin{array}{l}23 \\
1.10 \\
16.2 \\
11.5 \\
126\end{array}$ & $\begin{array}{l}32 \\
1.12 \\
17.5 \\
12.5 \\
140\end{array}$ & $\begin{array}{c}53 \\
1.13 \\
15.4 \\
11.5 \\
130\end{array}$ & $\begin{array}{c}0 \\
1.08 \\
14.8 \\
10.3 \\
112\end{array}$ & $\begin{array}{l}54 \\
1.12 \\
14.8 \\
11.8 \\
132\end{array}$ & $\begin{array}{l}90 \\
1.09 \\
13.2 \\
10.5 \\
113\end{array}$ & $\begin{array}{l}151 \\
1.13 \\
12.7 \\
9.6 \\
108\end{array}$ & $\begin{array}{l}0 \\
1.08 \\
14.4 \\
11.2 \\
121 .\end{array}$ & $\begin{array}{l}24 \\
1.13 \\
14.4 \\
11.1 \\
126\end{array}$ & $\begin{array}{l}38 \\
1.07 \\
11.1 \\
8.7 \\
92\end{array}$ & $\begin{array}{c}55 \\
1.09 \\
3.8 \\
10.7 \\
117\end{array}$ \\
\hline
\end{tabular}

(a) Data for formated samples was collected prior to the adjustment of the Wo/L for frit addition.

(b) Based on $T 0 / \mathrm{L}$ target of $125 \mathrm{~g} / \mathrm{L}$, no adjustment required. 
Test Plan which prescribes a target value of 150 gWO/L. (a) The designed target value was $125 \mathrm{gWO} / \mathrm{L}$. Because this, was not discovered until after initial runs were completed, Runs 1-10 were conducted with a simulant averaging 140 WO/L to maintain consistency for the perceived statistical analyses. The simulant oxide content was adjusted to $125 \mathrm{gWO} / \mathrm{L}$ after formating, prior to addition of frit. For Runs $11-13$, the simulant was adjusted to $125 \mathrm{gWO} / \mathrm{L}$ prior to formating. No trends related to formic acid addition or carbonate and nitrate addition were observed in these measured values.

\subsection{CHEMISTRY OF THE HWVP FORMATING STEP}

Addition of formic acid to HWVP feed results in two types of reactions: neutralization and redox. The feed chemistry as it relates to these two types of reactions is described prior to further discussion of results.

\subsubsection{Redox Reactions}

Formic acid is a fairly strong reducing agent. A generalized redox reaction with formic acid is

$$
\mathrm{HCOOH}+2 \mathrm{M}^{+3} \rightarrow \mathrm{CO}_{2}+2 \mathrm{H}^{+}+2 \mathrm{M}^{+2} \text {. }
$$

The redox chemistry of the simulant prepared for this study includes the reduction of $\mathrm{NO}_{3}^{-}, \mathrm{Fe}^{+3}, \mathrm{Cr}^{+6}, \mathrm{Mo}^{+6}$, and $\mathrm{Mn}^{+4}$ by formic acid. Identification of these components as active participants in redox reactions is based on, theoretical considerations (thermodynamic favorability of the redox reaction) and experimental data (detection of reduced species). Other potentialiy active redox species in HWVP feed include nitrite and organics.

Observations pertinent to this discussion are 1) ammonia [both as $\mathrm{NH}_{4}{ }^{+}(\mathrm{aq})$ and $\mathrm{NH}_{3}(\mathrm{~g})$ ] was detected in formated simulants; 2) $\mathrm{NO}_{2}(\mathrm{~g})$ was not visualiy observed; 3) the solubility of the chromium and molybdenum species decreased significantiy after formating, and 4) the solubility of manganese

(a) Prior to frit addition the measured $T O / L$ is referred to as waste oxide (WO)/L. After frit addition, the WO plus glass forming oxides in the frit are referred to as TO/L. 
species increased significantly after formating. Changes in solubility that may be attributed to changes in the redox state of $\mathrm{Cr}^{+6}, \mathrm{Mo}^{+6}$, and $\mathrm{Mn}^{+4}$ as a function of formic acid addition are discussed in Section 7.4.

For the feed simulant used in this study, $\mathrm{Fe}^{+3}$ and $\mathrm{NO}_{3}{ }^{-}$are of primary interest because their concentration in the simulant is greater than ten times that of the other potential redox participants. The reaction between formic acid and nitric acid has been studied by Healy, Longstaff, and Bradley. These systems involved high nitrate and acid content relative to the simulant used for this study. However, general trends are thought to be relevant and are therefore summarized below.

Healy observed that at nitric acid concentrations (1-4 M), nitric oxide (NO) rather than nitrogen dioxide $\left(\mathrm{NO}_{2}\right)$. was the major product. The gas composition for the reaction was $36 \% \mathrm{NO}, 4 \% \mathrm{NO}_{2}$, and $60 \% \mathrm{CO}_{2}$. For the HWVP simulant the concentration of nitrate would be considered low. The nitrate concentration in the test simulants ranged from 0.13 to $0.87 \mathrm{M}$. The reaction between nitric acid and formic acid for low acid concentrations may be defined as

$$
4 \mathrm{HNO}_{3}+6 \mathrm{HCOOH} \rightarrow 4 \mathrm{NO}+6 \mathrm{CO}_{2}+8 \mathrm{H}_{2} \mathrm{O} \text {. }
$$

Nitric oxide (NO) is oxidized in the presence of oxygen to nitrogen dioxide. However, the rate of this reaction is strongly concentration dependent, becoming in the order of minutes at low concentrations. Therefore, the 7 ack of $\mathrm{NO}_{2}$ detection during formating does not necessarily indicate the absence of NO.

It has been suggested that the rate determining step for the reaction between $\mathrm{HNO}_{3}$ and $\mathrm{HCOOH}$ involves nitrous acid as an intermediate. Longstaff and Singer reported that at low acidity the reaction rate was first order with respect to nitrous acid $\left(\mathrm{HNO}_{2}\right)$ and formic acid. The rate-determining step was postulated to be a bimolecular reaction between formic acid and nitrous acid in $<2.5 \mathrm{M}$ nitric acid. Healy suggested that the mechanism may involve the free radical, the formate ion $\left(\mathrm{HCO}_{2}^{-}\right)$, via the reaction 


$$
\mathrm{HCOOH}+\mathrm{HNO}_{2} \Rightarrow\left[\begin{array}{c}
\mathrm{O} \cdot \mathrm{NO} \\
\mathrm{HC}^{\prime} \\
\\
\\
0
\end{array}\right]+\mathrm{H}_{2} \mathrm{O} \Rightarrow \mathrm{HC}_{0}^{\prime}+\mathrm{NO}+\mathrm{H}_{2} \mathrm{O}
$$

The reactions between nitrate and formic acid addressed in the current study are listed below. Two gaseous products of nitrate reduction are considered: nitric oxide and ammonia. These reactions are based on the predicted formation of $\mathrm{NO}$ as supported by the studies summarized above and the detection of ammonia during the current study. The free energy of reaction is given for the formation of two types of gaseous products in both basic and acidic medias. Free energies of formation used to calculate the free energy of reaction are given in Table 7.8 .

Media BaTance Redox Equation

$\mathrm{G}^{\mathrm{O}} \mathrm{R}$

Product - NO

acid $6 \mathrm{HCOOH}(\mathrm{aq})+4 \mathrm{HNO}_{3} \rightarrow 6 \mathrm{CO}_{2}+4 \mathrm{NO}+8 \mathrm{H}_{2} \mathrm{O}(1)$

base $6 \mathrm{HCOO}^{-}(\mathrm{aq})+4 \mathrm{NO}_{3}^{-}+2 \mathrm{H}_{2} \mathrm{O} \rightarrow 6 \mathrm{CO}_{2}+4 \mathrm{NO}^{-10 \mathrm{OH}^{-}}-58$

Product - $\mathrm{NH}_{3} / \mathrm{NH}_{4}+$

acid $4 \mathrm{HCOOH}(\mathrm{aq})+\mathrm{HNO}_{3}+\mathrm{H}^{+} \rightarrow->4 \mathrm{CO}_{2}+\mathrm{NH}_{4}^{+}(\mathrm{aq})+3 \mathrm{H}_{2} \mathrm{O}(1)-50$

base $4 \mathrm{HCOO}^{-}(\mathrm{aq})+\mathrm{NO}_{3}^{-}+2 \mathrm{H}_{2} \mathrm{O}-\rightarrow 4 \mathrm{CO}_{2}+\mathrm{NH}_{3}(\mathrm{aq})+5 \mathrm{OH}^{-} \quad-60$

A17 four of these reactions are thermodynamically favorable as indicated by their negative free energies. Based on the equivalency of the free energy values, no one media or.product appears to be favored. (Note that this does not address the activation energy of the two competing reactions). The significant difference 7 ies in the stoichiometry. To produce ammonia, the mole ratio of formic acid to nitrate is 4 , compared with 1.5 required for production of NO. As is discussed in Section 7.5, the threshold for obtaining a detectable conversion of ferric ion to ferrous ion is between these two stoichiometric values, $\mathrm{HCOOH} / \mathrm{NO}_{3}=3$. Extracted from this observation is the 


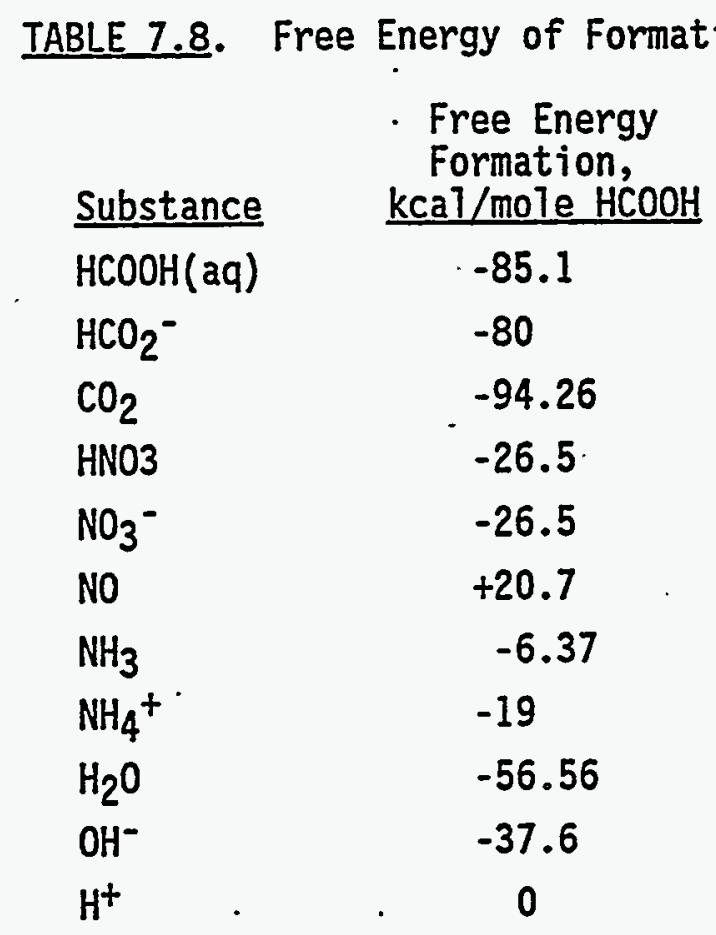

hypothesis that the extent of nitrate reduction can be correlated to the off gas composition. And that in turn, the extent of nitrate reduction can be related to the formic acid requirements.

\subsubsection{Hydrolys is Chemistry}

It is recommended in this study that the formic acid requirements be correlated to redox reactions rather than neutralization reactions. Therefore, the neutraization chemistry discussed in this section is 7 imited to the solubilization of feed components, as a basis for explaining the observed distribution of elements between supernate and solid phases. Measured distributions are discussed in Section 7.4 .

Based on the solubility equilibria constants and solubilities measured in the Taboratory, the cations of the HWVP feed are present primarily as insoluble hydroxide salts prior to formating with the following exceptions: 1) sodium, which exists as a soluble species, 2) lanthanum and neodydeum, which were added as insoluble fiuorides, 3 ) barium, which was added as an insoluble sulfate and 4) manganese, which is believed to exist as the insoluble oxide, $\mathrm{MnO}_{2}$, as it was added. Although copper and magnesium were 
added as sulfates during the simulant preparation, their respective hydroxides are much less soluble and would be expected to form under alkaline conditions.

The relative solubility of the hydroxide salts is reflected by their respective solubility constants. Table 7.9 lists the hydroxide solubility

TABLE 7.9. Solubility Constants for HWVP Feed Components

\begin{tabular}{|c|c|c|}
\hline Hydroxide & $\begin{array}{l}\text { Solubility } \\
\text { Constants } \\
\left(25^{\circ} \mathrm{C}\right) \\
\end{array}$ & Reference \\
\hline $\mathrm{Zr}(\mathrm{OH})_{4}$ & $\begin{array}{l}1.3 E-56 \\
1.1 E-54\end{array}$ & $\begin{array}{l}\text { Baes } \\
\text { Elinson }\end{array}$ \\
\hline $\begin{array}{l}\mathrm{Fe}(\mathrm{OH})_{3} \\
\mathrm{Al}(\mathrm{OH})_{3}\end{array}$ & $\begin{array}{r}4 \mathrm{E}-38 \\
1.9 \mathrm{E}-33 \\
3.16 \mathrm{E}-34\end{array}$ & $\begin{array}{l}\text { Latimer } \\
\text { Latimer } \\
\text { Baes }\end{array}$ \\
\hline $\mathrm{Cr}(\mathrm{OH})_{3}$ & $\begin{array}{l}7 E-31 \\
1 E-31\end{array}$ & $\begin{array}{l}\text { Latimer } \\
\text { Baes }\end{array}$ \\
\hline $\begin{array}{l}\mathrm{Pd}(\mathrm{OH})_{3} \\
\mathrm{La}(\mathrm{OH})_{3}\end{array}$ & $\begin{array}{r}E-24 \\
E-20 \\
2.0 E-22\end{array}$ & $\begin{array}{l}\text { Latimer } \\
\text { Latimer } \\
\text { Baes }\end{array}$ \\
\hline $\mathrm{Nd}(\mathrm{OH})_{3}$ & & $\begin{array}{l}\text { Latimer } \\
\text { Baes }\end{array}$ \\
\hline $\mathrm{Ce}(\mathrm{OH})_{3}$ & & $\begin{array}{l}\text { Latimer } \\
\text { Baes }\end{array}$ \\
\hline $\operatorname{Pr}(\mathrm{OH})_{3}$ & & $\begin{array}{l}\text { Latimer } \\
\text { Baes }\end{array}$ \\
\hline $\mathrm{Sm}(\mathrm{OH})_{3}$ & & $\begin{array}{l}\text { Latimer } \\
\text { Baes }\end{array}$ \\
\hline $\mathrm{Cu}(\mathrm{OH})_{2}$ & $\begin{array}{l}5.6 E-20 \\
4.4 E-20\end{array}$ & $\begin{array}{l}\text { Latimer } \\
\text { Baes }\end{array}$ \\
\hline $\begin{array}{l}\mathrm{Y}(\mathrm{OH})_{3} \\
\mathrm{Fe}(\mathrm{OH})_{2}\end{array}$ & $\begin{array}{r}3.2 \mathrm{E}-25 \\
1.6 \mathrm{E}-15 \\
7.08 \mathrm{E}-16\end{array}$ & $\begin{array}{l}\text { Baes } \\
\text { Latimer } \\
\text { Baes }\end{array}$ \\
\hline $\mathrm{Mn}(\mathrm{OH})_{2}$ & $\begin{array}{l}7.1 \mathrm{E}-15 \\
1.6 \mathrm{E}-13\end{array}$ & $\begin{array}{l}\text { Latimer } \\
\text { Baes }\end{array}$ \\
\hline $\begin{array}{l}\mathrm{Cd}(\mathrm{OH})_{2} \\
\mathrm{Ni}(\mathrm{OH})_{2}\end{array}$ & $\begin{array}{l}1.2 \mathrm{E}-14 \\
1.6 \mathrm{E}-14 \\
6.3 \mathrm{E}-18\end{array}$ & $\begin{array}{l}\text { Latimer } \\
\text { Latimer } \\
\text { Baes }\end{array}$ \\
\hline $\mathrm{Mg}(\mathrm{OH})_{2}$ & $\begin{array}{l}5.5 \mathrm{E} \\
6.9 \mathrm{E}\end{array}$ & $\begin{array}{l}\text { Latimer } \\
\text { Baes }\end{array}$ \\
\hline $\begin{array}{l}\mathrm{Ca}(\mathrm{OH})_{2} \\
\mathrm{Sr}(\mathrm{OH})_{2} \cdot 8 \mathrm{H}_{2} \mathrm{O} \\
\mathrm{Ba}(\mathrm{OH})_{2} \cdot 8 \mathrm{H}_{2} \mathrm{O} \\
\mathrm{NaOH} \\
\mathrm{RbOH} \\
\mathrm{CsOH}\end{array}$ & $\begin{array}{r}7.9 E-6 \\
3.2 E-4 \\
5 E-3\end{array}$ & $\begin{array}{l}\text { Latimer } \\
\text { Latimer } \\
\text { Latimer } \\
\text { Estimated } \\
\text { Estimated } \\
\text { Estimated }\end{array}$ \\
\hline
\end{tabular}


constants for a majority of the feed constituents. These constants may be used for relative comparison; however, these constants are dependent on the temperature, ionic strength, and species concentration. Kinetics also affects the dissolution process.

During titration of the feed with formic acid, dissolution of the hydroxides occurs when the hydroxide concentration becomes lower than that required to satisfy the equilibrium constant. With the exception of $\mathrm{Zr}, \mathrm{Fe}$, and possibily $\mathrm{Cr}$ and $\mathrm{Al}$, all of the hydroxides are predicted to be neutralized by formic acid as the $\mathrm{pH}$ decreases to approximately 4 . The extent to which these neutralization reactions occurred in the test simulant was measured by determining the concentration of the cation in the supernate as a function of formic acid addition and $\mathrm{pH}$. These results are discussed further in Section 7.4. The proposed neutralization reactions are: ${ }^{(a)}$

$$
\begin{aligned}
& \mathrm{CsOH}+\mathrm{HCOOH} \rightarrow \mathrm{CsCOOH}+\mathrm{H}_{2} \mathrm{O} \\
& \mathrm{RbOH}+\mathrm{HCOOH} \rightarrow \mathrm{RbCOOH}+\mathrm{H}_{2} \mathrm{O} \\
& \mathrm{NaOH}+\mathrm{HCOOH} \rightarrow \mathrm{NaCOOH}+\mathrm{H}_{2} \mathrm{O} \\
& \mathrm{Sr}(\mathrm{OH})_{2}+2 \mathrm{HCOOH} \rightarrow \mathrm{Sr}(\mathrm{COOH})_{2}+2 \mathrm{H}_{2} \mathrm{O} \\
& \mathrm{Na}_{2} \mathrm{CO}_{3}+2 \mathrm{HCOOH} \rightarrow 2 \mathrm{Na}(\mathrm{COOH})+\mathrm{H}_{2} \mathrm{CO}_{3}(\mathrm{~b}) \\
& \mathrm{Ca}(\mathrm{OH})_{2}+2 \mathrm{HCOH} \rightarrow \mathrm{Ca}(\mathrm{COOH})_{2}+2 \mathrm{H}_{2} \mathrm{O} \\
& \mathrm{Mg}(\mathrm{OH})_{2}+2 \mathrm{HCOOH} \rightarrow \mathrm{Mg}(\mathrm{COOH})_{2}+2 \mathrm{H}_{2} \mathrm{O} \\
& \mathrm{Ni}(\mathrm{OH})_{2}+2 \mathrm{HCOOH} \rightarrow \mathrm{Ni}(\mathrm{COOH})_{2}+2 \mathrm{H}_{2} \mathrm{O} \\
& \mathrm{Cd}(\mathrm{OH})_{2}+2 \mathrm{HCOOH} \rightarrow \mathrm{Cd}(\mathrm{COOH})_{2}+2 \mathrm{H}_{2} \mathrm{O} \\
& \mathrm{Y}(\mathrm{OH})_{3}+3 \mathrm{HCOOH} \rightarrow \mathrm{Y}(\mathrm{COOH})_{3}+3 \mathrm{H}_{2} \mathrm{O} \\
& \mathrm{Cu}(\mathrm{OH})_{2}+2 \mathrm{HCOOH} \rightarrow \mathrm{Cu}(\mathrm{COOH})_{2}+2 \mathrm{H}_{2} \mathrm{O} \\
& \mathrm{Sm}(\mathrm{OH})_{3}+3 \mathrm{HCOOH} \rightarrow \mathrm{Sm}(\mathrm{COOH})_{3}+3 \mathrm{H}_{2} \mathrm{O} \\
& \mathrm{Pr}(\mathrm{OH})_{3}+3 \mathrm{HCOH} \rightarrow \mathrm{Pr}(\mathrm{COOH})_{3}+3 \mathrm{H}_{2} \mathrm{O} \\
& \mathrm{Ce}(\mathrm{OH})_{3}+3 \mathrm{HCOOH} \rightarrow \mathrm{Ce}(\mathrm{COOH})_{3}+3 \mathrm{H}_{2} \mathrm{O} .
\end{aligned}
$$

(a) Notation, $M(\mathrm{COOH})_{\mathrm{R}}$, refers to either aqueous or insoluble salt:

(b) Carbonic acid decomposes into its anhydride and water in an acidic environment or with the addition of heat via the reaction

$$
\mathrm{H}_{2} \mathrm{CO}_{3} \rightarrow \mathrm{H}_{2} \mathrm{O}+\mathrm{CO}_{2}(\mathrm{~g}) \text {. }
$$

$\mathrm{CO}_{2}$ is only very slightly soluble in water and is released from solution. 


$$
\begin{array}{ll}
\mathrm{Pd}(\mathrm{OH})_{3}+3 . \mathrm{HCOOH} \rightarrow \mathrm{Pd}(\mathrm{COOH})_{3}+3 \mathrm{H}_{2} \mathrm{O} & \\
\mathrm{Al}(\mathrm{OH})_{3}+3 \mathrm{HCOOH} \rightarrow \mathrm{Al}(\mathrm{COOH})_{3}+3 \mathrm{H}_{2} \mathrm{O} & \text { [dissolution at } \mathrm{pH}<5 \text { ] } \\
\mathrm{Cr}(\mathrm{OH})_{3}+3 \mathrm{HCOOH} \rightarrow \mathrm{Cr}(\mathrm{COOH})_{3}+3 \mathrm{H}_{2} \mathrm{O} & \text { [excessive (151 ml/L) formic } \\
\mathrm{Fe}(\mathrm{OH})_{3}+3 \mathrm{HCOOH} \rightarrow \mathrm{Fe}(\mathrm{COOH})_{3}+3 \mathrm{H}_{2} \mathrm{O} & \begin{array}{l}
\text { acid addition, onfy] } \\
\text { [excessive (151 ml } / \mathrm{L}) \text { formic }
\end{array} \\
& \text { acid addition, only] }
\end{array}
$$

Similar reactions are given by Farnsworth. (1987). Farnsworth did not include calcium, palladium, and cadmium. Farnsworth did include manganese, lanthanum, and neodyneum. Neodyneum and lanthanum are not included as these cations are believed to exist as the highly insoluble fluorides which they were added. Manganese was added as insoluble $\mathrm{MnO}_{4}$ and would precipitate as $\mathrm{Mn}(\mathrm{OH})_{2}$ only after reduction, $\mathrm{Mn}^{+4} \rightarrow \mathrm{Mn}^{+2}$. Based on experimental data reported in Section 7.4, chromium and ferric hydroxide solubilize only after excessive amounts of formic acid $(151 \mathrm{~m} / / \mathrm{L})$ are added.

The neutralization reactions presented above represent a simplistic view of the actual hydrolysis chemistry of the feed. In reality the hydrolysis products exists both as aqueous species (hydrated oxides) and as solids (hydroxide salts). Equilibria between these species may be expressed by the following equations. (a)

Aqueous Cation, $M^{+Z}$, to a Soluble Hydrated Oxide

$$
x M^{+Z}+y_{2} \mathrm{O}\left\langle--->M x(\mathrm{OH})_{y}(x z-y)++\mathrm{yH}^{+} \quad K_{x y}=\frac{\left[M x(\mathrm{OH})_{y}(\mathrm{Xz}-\mathrm{y})+\right]\left[\mathrm{H}^{+}\right]^{y}}{\left[M^{+z}\right]^{x}}\right.
$$

Hydroxide Sa7t, $\mathrm{M}(\mathrm{OH})_{z}$, to a Soluble Hydrated Oxide

$x M(O H)_{z}(s)+H^{+}\left\langle-->M_{x}(\mathrm{OH})_{y}(x z-y)++H_{2} \mathrm{O} \quad \cdot K_{s x y}=\frac{\left[M_{x}(\mathrm{OH})_{y}(x z-y)+\right]}{\left[\mathrm{H}^{+}\right]_{x z-y}}\right.$

(a) As a first approximation the formation constant, $K$, is assumed to be equal to the formation quotient, $Q$. This implies that the activity coefficients for the reacting species are equal to one. 
Solubilization of a hydroxide salt can also be represented as:

$$
\begin{gathered}
x M(\mathrm{OH})_{z}(s) \longleftrightarrow--->M_{x}(\mathrm{OH})_{y}(x z-y)++(x z-y) \mathrm{OH}^{-} \\
K_{s x y}^{b}=\left[M_{x}(\mathrm{OH})_{y}(x z-y)+\right]\left[\mathrm{OH}^{-}\right](x z-y)
\end{gathered}
$$

$\mathrm{K}^{\mathrm{b}}{ }_{s x y}$ is related to $\mathrm{K}_{\mathrm{sxy}}$ by the dissociation product of water, $\mathrm{K}_{\mathrm{W}}$ :

$$
\begin{aligned}
K_{W} & =\left[\mathrm{H}^{+}\right]\left[\mathrm{OH}^{-j}\right] . \\
\mathrm{K}^{\mathrm{b}}{ }_{s x y} & =K_{s x y} K_{W} x z-y
\end{aligned}
$$

Formation constants $\left(K_{x y}\right)$ for hydrated oxides are listed in Table 7.10. Solubility constants $\left(K^{b}{ }_{s x y}\right)$ for hydroxide are listed in Table 7.11.

\subsection{SOLUBILITY MEASUREMENTS}

For Runs 12 and 13, in addition to the total simulant composition, the fraction of soluble species was determined by compositional analysis of the supernate. Table 7.12 Tists the composition of the simulant and soluble - fractions for these tests.

The significant changes in solubility as a function of formic acid addition are described below and summarized in Table 7.13. These results are compared with those reported by Goles and Nakaoka (1989) for the PSCM-23 run. Differences in solubility behavior for Run 12, Run 13 and PSCM-23 are explained by differences in the $\mathrm{pH}$ after reflux (post reflux). A potential reaction scenario for chromium behavior during the formating step is also given.

\subsubsection{Ions that Increase in Solubility After Formating}

The increase in solubility of aluminum, calcium, strontium, magnesium, and cadmium is attributed to neutralization of their respective hydroxide salts by formic acid. This was observed during Run 12 and the PSCM-23 run. For Run 13 the carbonate loading was approximately 13 times greater than in Run 12. During Run 13 formic acid was consumed by neutralization of the 
TABLE 7.10. Formation Constants for Hydrated Oxides in HWVP Feed(a)

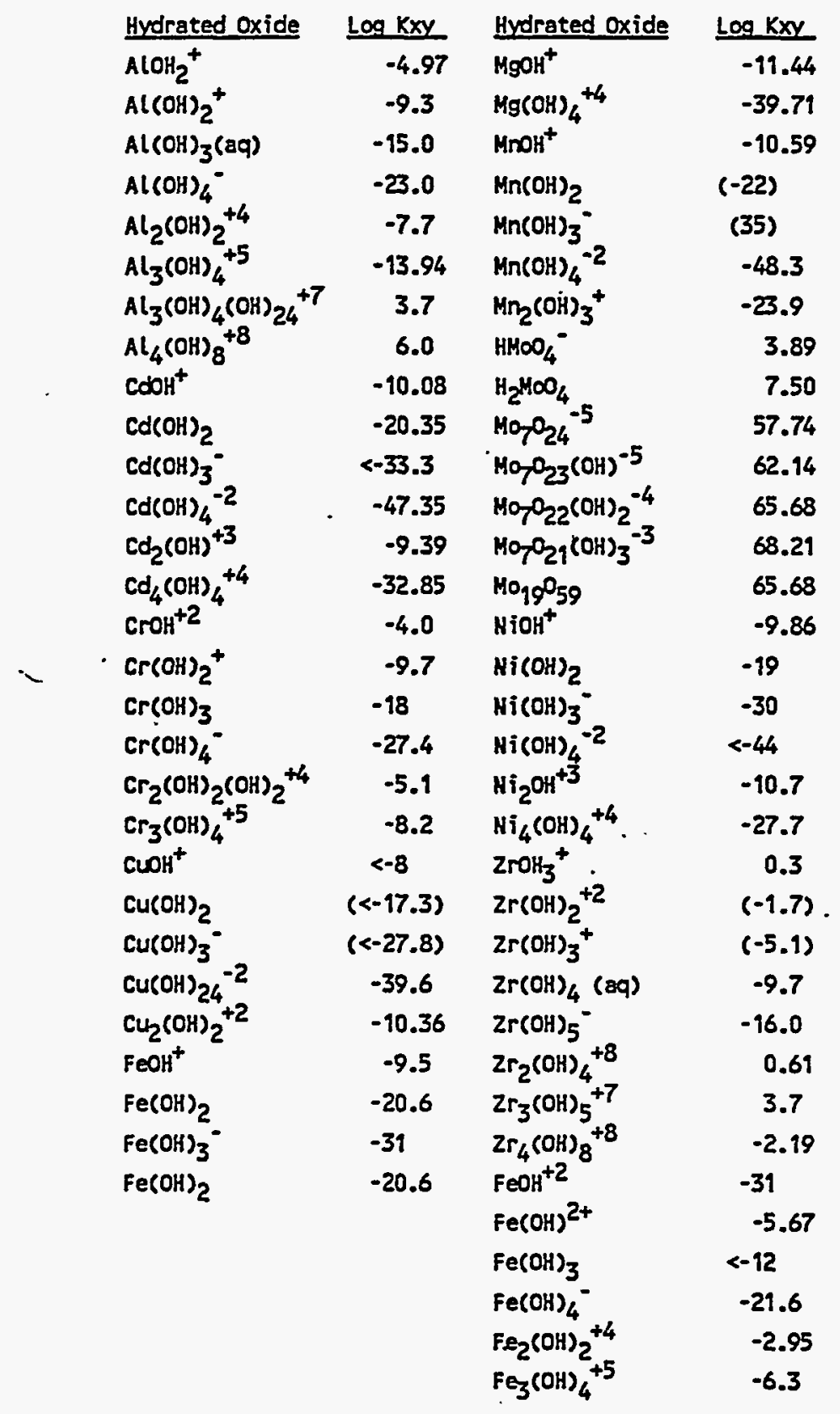

(a) Values extracted from Baes, 1986.

carbonate and not available for neutralization of the hydroxide salts. Therefore, the solubility changes which result from neutralization of the hydroxides are negligible for Run 13. The potential impact of end point $\mathrm{pH}$ during formating is discussed further in Section 7.6. 
TABLE 7.11. Solubility Constants for Hydroxide Salts in HWVP Feed(a)

\begin{tabular}{|c|c|}
\hline Hydroxide Salt & Log $K_{s x y}$ \\
\hline$\alpha-\mathrm{Al}(\mathrm{OH})_{3}$ & 8.5 \\
\hline $\mathrm{Ce}(\mathrm{OH})_{3}$ & 19.9 \\
\hline$\beta-\mathrm{Cd}(\mathrm{OH})_{2}$ & 13.65 \\
\hline $\mathrm{Cr}(\mathrm{OH})_{3}$ & 12 \\
\hline $\mathrm{Cu}(\mathrm{OH})_{2}$ & 8.64 \\
\hline CuO & 7.62 \\
\hline $\mathrm{Fe}(\mathrm{OH})_{2}$ & 12.85 \\
\hline$\alpha-\mathrm{FeO}(\mathrm{OH})$ & 0.5 \\
\hline $\mathrm{La}(\mathrm{OH})_{3}$ & 20.3 \\
\hline $\mathrm{Mb}(\mathrm{OH})_{2}$ & 16.84 \\
\hline $\mathrm{Mn}(\mathrm{OH})_{2}$ & 15.2 \\
\hline $\mathrm{MoO}_{3}$ & -12.06 \\
\hline $\mathrm{Ni}(\mathrm{OH})_{2}$ & 10.8 \\
\hline $\mathrm{Nd}(\mathrm{OH})_{3}$ & 18.6 \\
\hline $\operatorname{Pr}(\mathrm{OH})_{3}$ & 19.5 \\
\hline $\mathrm{Sm}(\mathrm{OH})_{3}$ & 16.5 \\
\hline $\mathrm{Y}(\mathrm{OH})_{3}$ & 17.5 \\
\hline $\mathrm{ZrO}_{2}$ & -1.9 \\
\hline
\end{tabular}

(a) Values extracted from Baes 1986.

Manganese solubility increased during the addition of formic acid in Run 12 and $\mathrm{PSCM}-23$. The increase in solubility may be attributed to the reduction of the insoluble $\mathrm{MnO}_{2}$ (species as added to simulant) to $\mathrm{Mn}^{+2}$ by formic acid. In an acid environment (Run 12 and PSCM-23) this species would be soluble. In an alkaline environment (Run 13$), \mathrm{Mn}(\mathrm{OH})_{2}$ would be precipitated. Significantly less manganese was soluble in Run 13 formated simulant.

The dissolution of $\mathrm{Fe}(\mathrm{OH})_{3}(-20 \%)$ was observed at relatively high post reflux acidity, after an excessive amount of formic acid addition (151 $\mathrm{ml} / \mathrm{L})$ in Run 12. The $\mathrm{pH}$ after formic acid addition was 3.09; after reflux the $\mathrm{pH}$ 
TABLE 7.12. Solubility Data for Runs 12 and 13

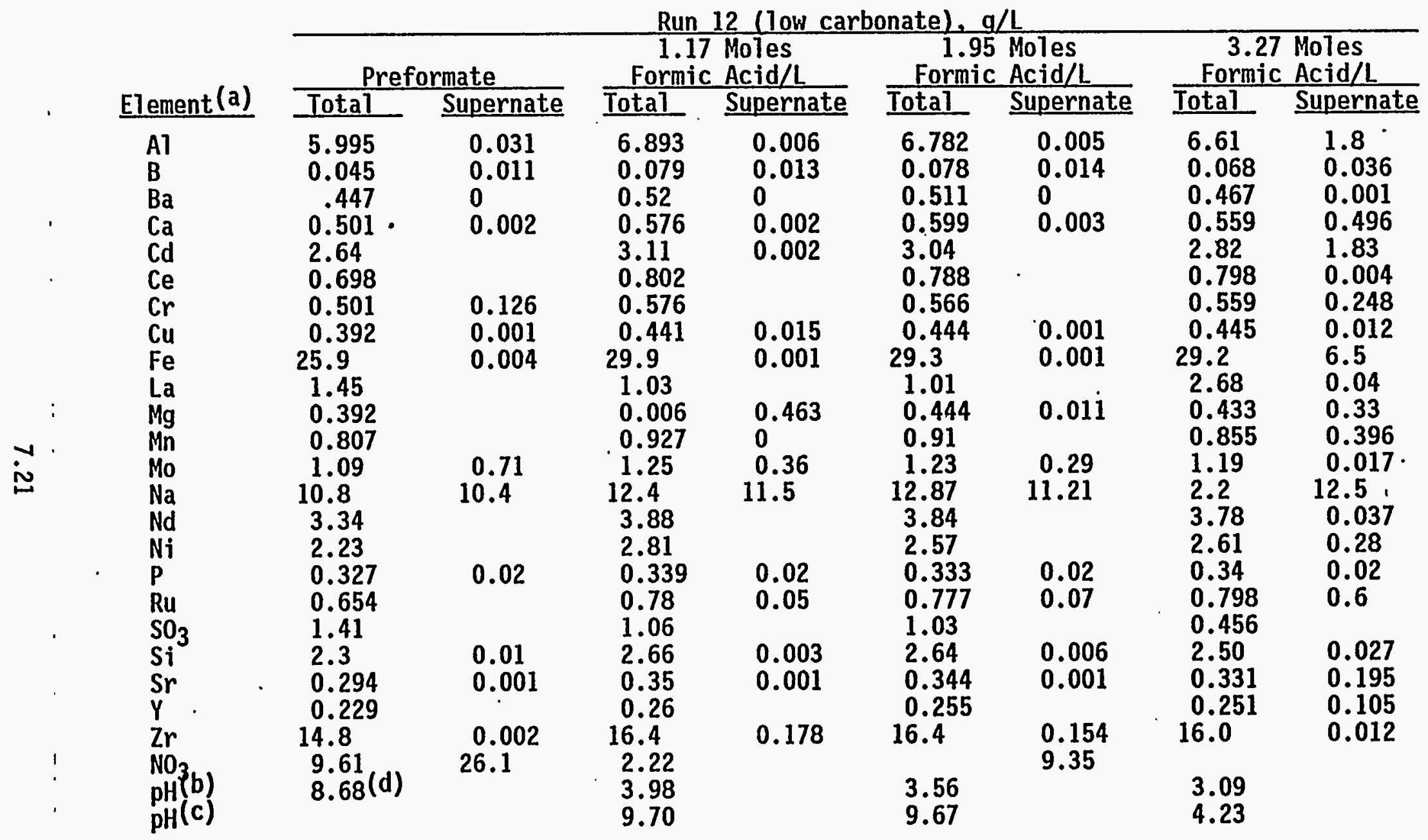


TABLE 7.12. (contd)

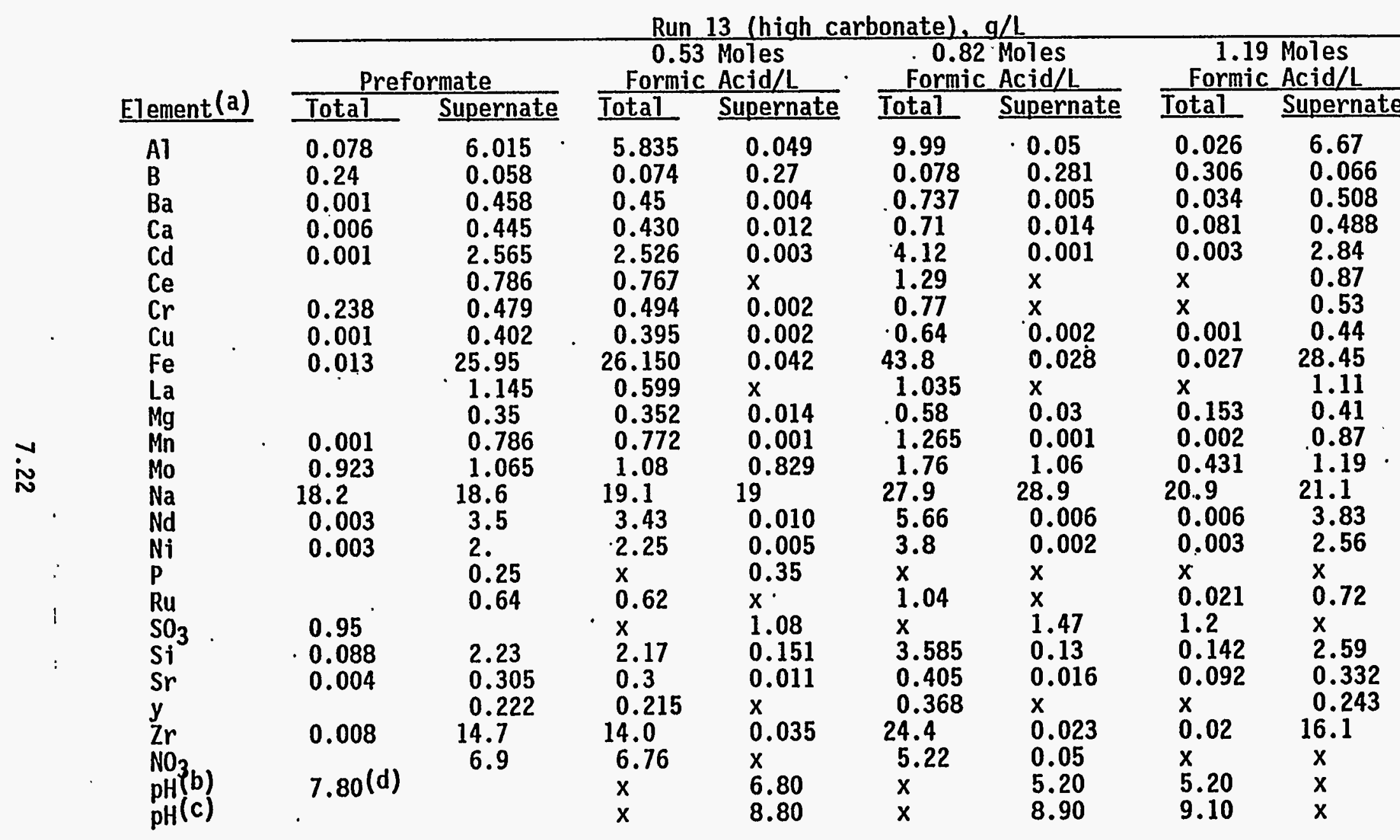

(a) Fluoride data not reproducible. $\mathrm{Pd}, \mathrm{Pr}, \mathrm{Rb}, \mathrm{Rh}, \mathrm{Sm}$, and $\mathrm{CO}_{3}$ not measured. Bịanks represent concentrations below detection limit.

(b) Minimum $\mathrm{pH}$ at indicated formic acid addition.

(c) $\mathrm{pH}$ after $2 \mathrm{hr}$ reflux.

(d) Initial $\mathrm{pH}$ measured at $95^{\circ} \mathrm{C}$ (corrected for temperature). 
TABLE $\dot{7} .13$. Comparison of Solubility Behavior for Run 12, Run 13 and PSCM-23

$\%$ Soluble Prior to and After Formating/Reflux Step

\begin{tabular}{|c|c|c|c|}
\hline Element & Run $12(\mathrm{pH} 4.2)(\mathrm{a})$ & Run 13 (pH 9.0) & SCM-23 (pH 4.2) \\
\hline \multicolumn{4}{|c|}{ Neutralization } \\
\hline A1 & $<1 \%$ to $10 \%$ & $<1 \%$ throughout & $<1 \%$ to $9 \%$ \\
\hline $\mathrm{Ca}$ & $<1 \%$ to $31 \%$ & $<1 \%$ throughout & $<1 \%$ to $95 \%$ \\
\hline $\mathrm{Cd}$ & $<1 \%$ to $23 \%$ & $<1 \%$ throughout & not measured \\
\hline $\mathrm{Mg}$ & $<1 \%$ to $26 \%$ & $<1 \%$ to $5.5 \%$ & $<5 \%$ to $100 \%$ \\
\hline$S r$ & $<1 \%$ to $21 \%$ & $<1 \%$ throughout & $<5 \%$ to $59 \%$ \\
\hline \multicolumn{4}{|l|}{ Redox } \\
\hline$M n$ & $<1 \%$ to $16 \%$ & $<1 \%$ throughout & $<1 \%$ to $70 \%$ \\
\hline $\mathrm{Cr}$ & $6 \%$ to $<4 \%$ to $16 \%$ & $26 \%$ to $<1 \%$ & $20 \%$ to $10 \%$ \\
\hline Mo & $16 \%$ to $0.5 \%$ & $50 \%$ to $6 \%$ & $30 \%$ to $45 \%$ \\
\hline
\end{tabular}

(a) $\mathrm{pH}$ of feed after formic acid addition and 2-h reflux.

was 4.23. In a17 other. cases for Runs 12 and 13 the post reflux pH was $\sim 9$ and $>99 \%$ of $\mathrm{Fe}^{+3}$ was present as a solid.

\subsubsection{Ions that Decrease in Solubility After Formating}

During Run 13 the solubility of molybdenum steadily decreased from $50 \%$ to $6 \%$ and the solubility of chromium decreased from $26 \%$ to below detection limit $(\langle 4 \%)$. This same behavior was reported for samples collected during the PSCM-23 run (Goles and Nakoaka 1989) and is believed to be associated with changes in redox states.

During Run 12 , the solubility of molybdenum also decreased from $17 \%$ to $1 \%$. For this same test, the concentration of chromium in the supernate phase decreased from $7 \%$ to $<4 \%$ down to a $\mathrm{pH} 3.6$. As the formic acid loading increased from $90 \mathrm{ml} / \mathrm{L}$ to $151 \mathrm{mT} / \mathrm{L}$ the $\mathrm{pH}$ decreased to 3.1 and chromium ion solubility increased. This increase in solubility is most likely due to the solubilization of the $\mathrm{Cr}(\mathrm{OH})_{3}$ hydroxide in the presence of excess acid. A reaction scenario for chromium is described below. 


\subsubsection{Proposed Reaction Scenario for Chromium}

The following reactions describe the proposed scenario for chromium ion behavior during the feed preparation steps:

$2 \mathrm{Cr}^{+3}+3 \mathrm{NO}_{3}^{-}+3 \mathrm{H}_{2} \mathrm{O} \rightarrow 2 \mathrm{Cr}^{+6}+3 \mathrm{NO}_{2}^{-}+6 \mathrm{OH}^{-}$

$2 \mathrm{Cr}^{+6}+3 \mathrm{HCOOH}+2 \mathrm{Cr}^{+3}+3 \mathrm{CO}_{2}+6 \mathrm{H}^{+}$

$\mathrm{Cr}+3+3 \mathrm{OH}^{-} \rightarrow \mathrm{Cr}(\mathrm{OH})_{3}$ ( $\mathrm{SOTid)}$

$\mathrm{Cr}(\mathrm{OH})_{3}+3 \mathrm{H}^{+} \rightarrow \mathrm{Cr}^{+3}+3 \mathrm{H}_{2} \mathrm{O}$ (excess formic acid).

Evaluation of the data which support this scenario are presented below.

These data are derived from Run 13 samples of initial simulant and formated simulant with $24 \mathrm{mT} 90 \mathrm{wt} \%$ formic acid/L ( 0.53 moles formic acid/L). Initial simulant - Twenty-six percent of the chromium is soluble as the Cr+6 species.

- 0.0024 moles out of a total 0.0092 moles chromium (26\%) was soluble in the simulant.

- The initial pH of this simulant was. 7.8, being buffered by a high bicarbonate loading. The initial pH of simulants without carbonate ranged from 9-10. In an alkaline environment, the remaining chromium as $\mathrm{Cr}^{+3}$ would precipitate as the hydroxide.

- Chromium (+6) was the predominant, soluble chromium species in the alkaline supernate. Colormetric analysis for $\mathrm{Cr}^{+6}$ concentration agreed within $2 \%$ of the ICP analysis for chromium in the supernate.

- Chromium was added to the simulant in the +3 valence state. Oxidation of chromium $(+3)$ to $\mathrm{Cr}(+6)$ may have resulted from the presence of nitrate (Equation 1); a thermodynamically favorable reaction.

Formated Simulant $-\mathrm{Cr}^{+6}$ is reduced by formic acid and precipitates as $\mathrm{Cr}(\mathrm{OH})_{3}$.

- After addition of $24 \mathrm{mT} 90 \mathrm{wt} \%$ formic acid/L simulant $(0.53$ moles formic acid/L), the concentration of chromium in the supernate decreased to below the ICP detection limit for chromium $(0.00038 \mathrm{moles} / \mathrm{L})$. This may be attributed to the reduction of $\mathrm{Cr}+6$ to $\mathrm{Cr}^{+3}$ (Equation 2) and subsequent precipitation of the $\mathrm{Cr}^{+3}$ as a hydroxide $\left(K_{s p}=6.7 \mathrm{E}-31\right)$ (Equation 3 ). 
- The moles of $\mathrm{Cr}^{+6}$ reduced is but a small fraction of the total amount of formic acid added. Considering that three moles of formic acid react with two moles of $\mathrm{Cr}^{+6}$ to produce $\mathrm{Cr}+3$, the fraction of formic acid consumed is $0.002 * 1.5 / 0.53=0.57 \%$.

- In the presence of excess acid (151 $\mathrm{ml} 90 \mathrm{wt} \%$ formic acid/L, the hydroxide would dissolve (Equation 4) (Run 12).

\subsection{FORMIC ACID REQUIREMENTS}

The formic acid requirements are discussed in terms of dependency on carbonate, nitrate, and initial $\mathrm{Fe}^{+3}$ feed content.

Carbonate decomposes to $\mathrm{CO}_{2}$ as the feed is acidified with formic acid and as the feed is heated to $1000{ }^{\circ} \mathrm{C}$ for vitrification. The \% decomposition as a function of process step is not known. This decomposition reaction is

$$
\mathrm{H}_{2} \mathrm{CO}_{3}-\cdots \mathrm{H}_{2} \mathrm{O}+\mathrm{CO}_{2} \text {. }
$$

Unlike formic acid, the carbon in carbonate and $\mathrm{CO}_{2}$ is in its maximum oxidation state, +4. Therefore, neither the $\mathrm{CO}_{3}^{-2}$ nor the $\mathrm{CO}_{2}$ would be expected to act as reducing agents during formic acid addition or in the vitrification step. The endpoint $\mathrm{pH}$ after formating high carbonate simulants was less acidic. The relationship between acidity and the process step at which redox occurs is discussed further in Section 7.6.

A glass $\mathrm{Fe}^{+2} / \mathrm{Fe}^{+3}$ ratio of 0.08 was measured for both Runs 6 (high carbonate) and 8 (10w carbonate) at equivalent formic acid and nitrate Toadings. This finding suggested that redox participants such as nitrate, should provide the primary criteria for formic acid adjustments. After evaluation of subsequent runs, a threshold for obtaining an acceptable glass $\mathrm{Fe}^{+2} / \mathrm{Fe}^{+3}$ ratio was defined independent of carbonate concentrations in the range of 8 to $59 \mathrm{~g} / \mathrm{L}$.

The nitrate ion content in the feed is a significant factor in the determination of the formic acid requirement for glass redox adjustments. The significance of the $\mathrm{HCOOH} / \mathrm{HNO}_{3}$ ratio is attributed to the consumption of formic acid through the reduction of the nitrate ion to produce ammonia and/or nitrogen oxide/nitrogen dioxide/nitrous oxide and carbon dioxide. 
This reaction may take $\mathrm{place}$ during the formating and/or the melting $\operatorname{step}(s)$. Ammonia was observed during the current studies and reported as an off gas component from the melter for the PSCM-23 run (Goles and Nakaoka 1989). Release of $\mathrm{NO}_{x}, \mathrm{~N}_{2} \mathrm{O}$, and $\mathrm{CO}_{2}$ during formating has been measured previously (Wiemers 1987).

In Figure 7.3 the $\mathrm{glass} \mathrm{Fe}^{+2} / \mathrm{Fe}^{+3}$ ratio is plotted as a function of $\mathrm{HCOOH} / \mathrm{NO}_{3}$ for Runs 1-13. A detectable glass redox is measured after the mole ratio, $\mathrm{HCOOH} / \mathrm{NO}_{3}$, is greater than 3.

Addition of the 32 data points collected by Farnsworth (1987) suggests two relationships: 1) glass redox is dependent on $\mathrm{Fe}^{+3}$ initial $/ \mathrm{NO}_{3}$ and 2) for reference feed, $\mathrm{Fe}^{+3} / \mathrm{NO}<4$, a minimum requirement for redox adjustments is $\mathrm{HCOOH} / \mathrm{NO}_{3}=3$. Detectable $\mathrm{Fe}^{+2} / \mathrm{Fe}^{+3}(\geq 0.005)$ ratios were measured for all samples with $\mathrm{HCOOH} / \mathrm{NO}_{3} \geq 3$. Farnsworth's data is plotted with data from this study in Figure 7.4. The collated data is listed in Table 7.14.

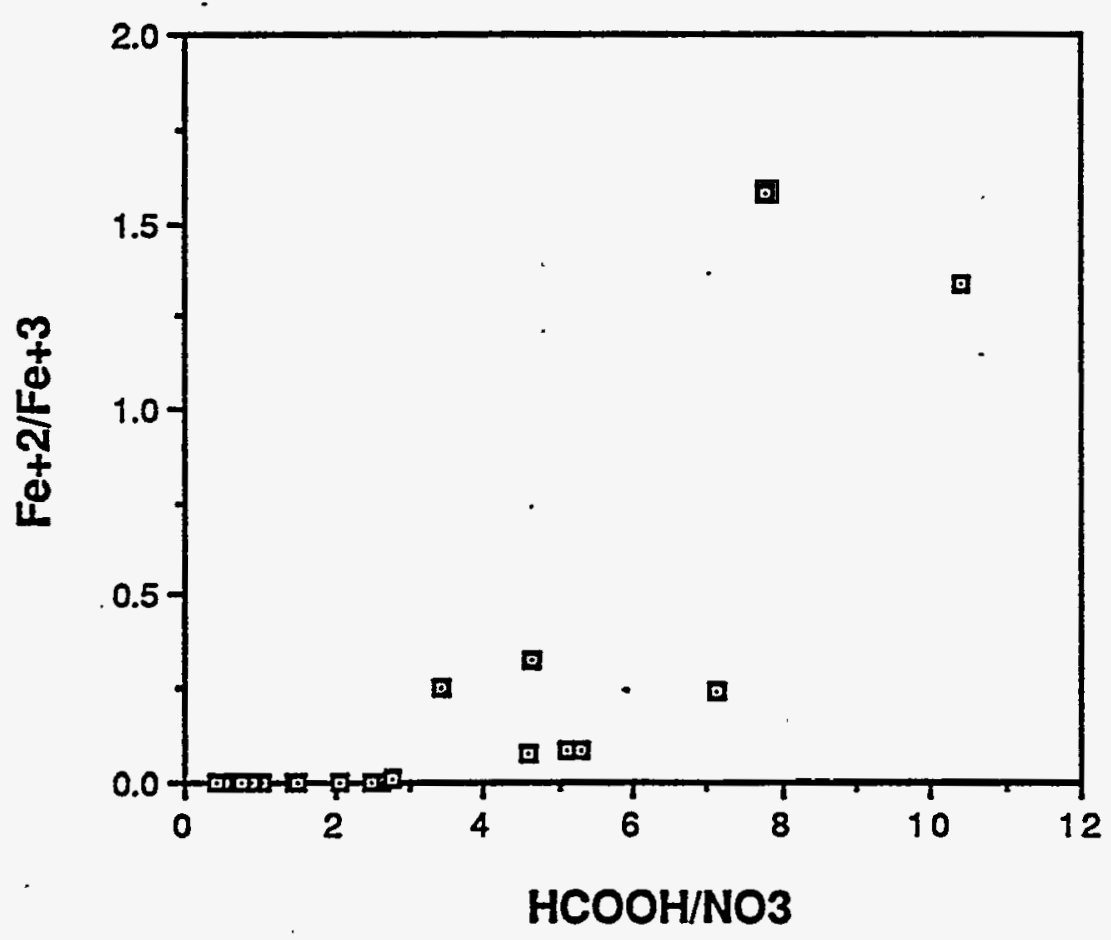

FIGURE 7.3. Dependence of Glass Redox on $\mathrm{HCOOH} / \mathrm{NO}_{3}$ 


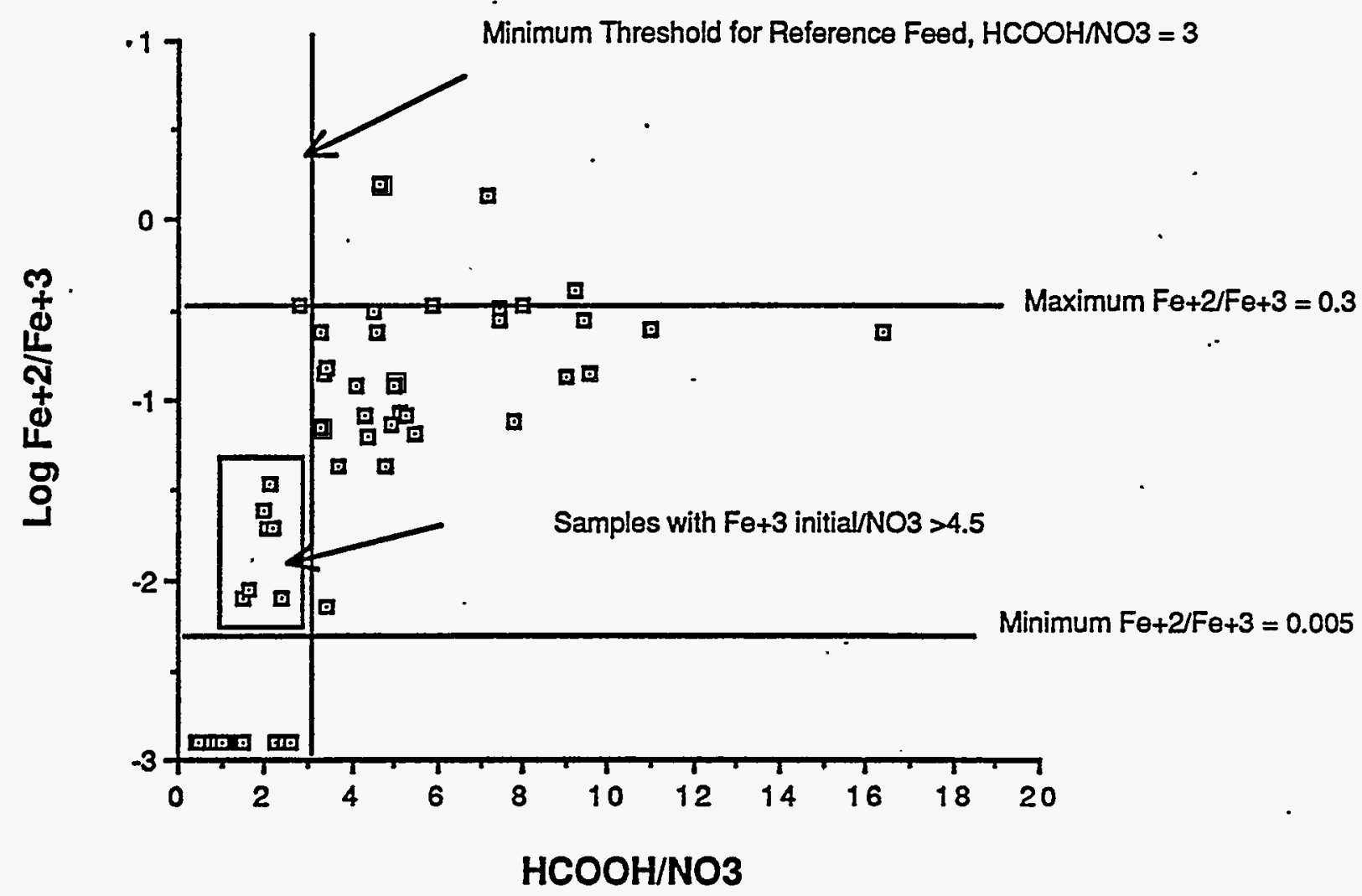

FIGURE 7.4. Threshold for $\mathrm{HCOOH} / \mathrm{NO}_{3}$ and $\mathrm{Fe}+2 / \mathrm{Fe}^{+3}$ Relationship

In the presence of high iron $\left(\mathrm{Fe} / \mathrm{NO}_{3}>4\right)$ the formic acid requirements for acceptable glass redox were less, $\mathrm{HCOOH} / \mathrm{NO}_{3}=1.5$ to 2.5. It is speculated that the variation in the formic acid requirements may be attributed to differences in the ratio of nitrate redox reaction products, $\mathrm{NO}, \mathrm{NO}_{2}, \mathrm{~N}_{2} \mathrm{O}$ and $\mathrm{NH}_{3}$.

The scatter of data observed after the threshold may be attributed to differences between laboratory formating procedures, vitrification conditions, and secondary reactions which become more significant once the $\mathrm{HCOOH} / \mathrm{NO}_{3}$ threshold is met. For example, Farnsworth's simulants also contained varying amounts of the organic, oxalic acid.

Based on the observed threshold for the reference feed, $\mathrm{HCOOH} / \mathrm{NO}_{3}=3$, the formic acid requirements for the target low, nominal, and high nitrate 
TABLE 7.14. $\mathrm{HCOOH} / \mathrm{NO}_{3}$ Threshold Support Data

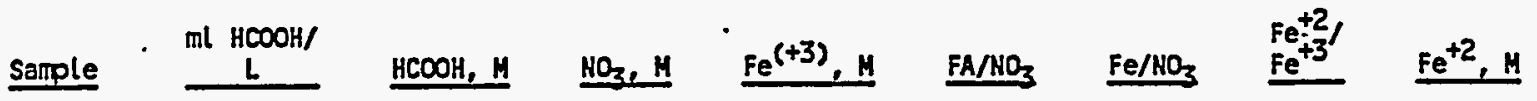

Farnsworth 1987

\begin{tabular}{|c|c|c|c|c|c|c|c|c|}
\hline 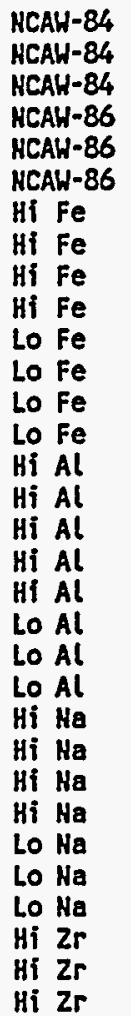 & $\begin{array}{l}14 \\
24 \\
48 \\
12 \\
26 \\
36 \\
10 \\
24 \\
44 \\
80 \\
24 \\
36 \\
44 \\
80 \\
12 \\
24 \\
32 \\
40 \\
.80 \\
10 \\
20 \\
44 \\
12 \\
30 \\
51 \\
80 \\
12 \\
24 \\
48 \\
8 \\
20 \\
32\end{array}$ & $\begin{array}{l}0.30 \\
0.52 \\
1.04 \\
0.26 \\
0.56 \\
0.78 \\
0.22 \\
0.52 \\
0.95 \\
1.74 \\
0.52 \\
0.78 \\
0.95 \\
1.74 \\
0.26 \\
0.52 \\
0.69 \\
0.87 \\
1.74 \\
0.22 \\
0.43 \\
0.95 \\
0.26 \\
0.65 \\
1.11 \\
1.74 \\
0.26 \\
0.52 \\
1.04 \\
0.17 \\
0.43 \\
0.69\end{array}$ & $\begin{array}{l}0.14 \\
0.14 \\
0.14 \\
0.17 \\
0.17 \\
0.17 \\
0.11 \\
0.11 \\
0.11 \\
0.11 \\
0.23 \\
0.23 \\
0.23 \\
0.23 \\
0.16 \\
0.16 \\
0.16 \\
0.16 \\
0.16 \\
0.10 \\
0.10 \\
0.10 \\
0.19 \\
0.19 \\
0.19 \\
0.19 \\
0.11 \\
0.11 \\
0.11 \\
0.09 \\
0.09 \\
0.09\end{array}$ & $\begin{array}{l}0.94 \\
0.94 \\
0.94 \\
0.55 \\
0.55 \\
0.55 \\
1.15 \\
1.15 \\
1.15 \\
1.15 \\
0.22 \\
0.22 \\
0.22 \\
0.22 \\
0.86 \\
0.86 \\
0.86 \\
0.86 \\
0.86 \\
1.05 \\
1.05 \\
1.05 \\
0.85 \\
0.85 \\
0.85 \\
0.85 \\
1.01 \\
1.01 \\
1.01 \\
0.58 \\
0.58 \\
0.58\end{array}$ & $\begin{array}{r}2.17 \\
3.72 \\
7.44 \\
1.51 \\
3.26 \\
4.52 \\
2.05 \\
4.91 \\
9.01 \\
16.38 \\
2.24 \\
3.35 \\
4.10 \\
7.45 \\
1.65 \\
3.30 \\
4.39 \\
5.49 \\
10.99 \\
2.15 \\
4.30 \\
9.45 \\
1.38 \\
3.44 \\
5.88 \\
9.19 \\
2.39 \\
4.78 \\
9.56 \\
2.00 \\
4.99 \\
7.98\end{array}$ & $\begin{array}{r}6.72 \\
6.72 \\
6.72 \\
3.16 \\
3.16 \\
3.16 \\
10.88 \\
10.88 \\
10.88 \\
10.88 \\
0.96 \\
0.96 \\
0.96 \\
0.96 \\
5.42 \\
5.42 \\
5.42 \\
5.42 \\
5.42 \\
10.44 \\
10.44 \\
10.44 \\
4.51 \\
4.51 \\
4.51 \\
4.51 \\
9.28 \\
9.28 \\
9.28 \\
6.63 \\
6.63 \\
6.63\end{array}$ & $\begin{array}{l}0.020 \\
0.043 \\
0.272 \\
0.008 \\
0.235 \\
0.312 \\
0.020 \\
0.074 \\
0.136 \\
0.235 \\
0.003 \\
0.141 \\
0.121 \\
0.319 \\
0.009 \\
0.071 \\
0.064 \\
0.067 \\
0.252 \\
0.035 \\
0.083 \\
0.281 \\
0.002 \\
0.152 \\
0.334 \\
0.406 \\
0.008 \\
0.044 \\
0.141 \\
0.025 \\
0.119 \\
0.335\end{array}$ & $\begin{array}{l}0.018 \\
0.039 \\
0.201 \\
0.004 \\
0.104 \\
0.130 \\
0.023 \\
0.079 \\
0.138 \\
0.219 \\
0.001 \\
0.028 \\
0.024 \\
0.054 \\
0.008 \\
0.057 \\
0.052 \\
0.054 \\
0.172 \\
0.036 \\
0.081 \\
0.231 \\
0.002 \\
0.113 \\
0.214 \\
0.246 \\
0.008 \\
0.043 \\
0.125 \\
0.014 \\
0.061 \\
0.145\end{array}$ \\
\hline
\end{tabular}

Data from Current Study

\begin{tabular}{|c|c|c|c|c|c|c|c|c|}
\hline $\begin{array}{l}\text { Run } 1 \\
\text { Run } 2 \\
\text { Run } 3 \\
\text { Run } 4 \\
\text { Run } 5 \\
\text { Run } 6 \\
\text { Run } 7 \\
\text { Run } 8 \\
\text { Run } 9 \\
\text { Run } 10 \\
\text { Run } 11 \\
\text { Run } 11 \\
\text { Run } 11 \\
\text { Run } 12 \\
\text { Run } 12 \\
\text { Run } 12 \\
\text { Run } 13 \\
\text { Run } 13 \\
\text { Run } 13\end{array}$ & $\begin{array}{r}22 \\
31 \\
16 \\
16 \\
15 \\
32 \\
31 \\
31 \\
16 \\
22 \\
23 \\
32 \\
53 \\
54 \\
90 \\
151 \\
24 \\
38 \\
55\end{array}$ & $\begin{array}{l}0.47 \\
0.67 \\
0.34 \\
0.35 \\
0.32 \\
0.69 \\
0.67 \\
0.66 \\
0.35 \\
0.48 \\
0.50 \\
0.69 \\
1.15 \\
1.17 \\
1.95 \\
3.28 \\
0.53 \\
0.82 \\
1.19\end{array}$ & $\begin{array}{l}0.46 \\
0.74 \\
0.13 \\
0.69 \\
0.13 \\
0.13 \\
0.88 \\
0.13 \\
0.87 \\
0.33 \\
0.34 \\
0.34 \\
0.34 \\
0.42 \\
0.42 \\
0.42 \\
0.12 \\
0.12 \\
0.12\end{array}$ & $\begin{array}{l}0.50 \\
0.50 \\
0.50 \\
0.50 \\
0.50 \\
0.50 \\
0.50 \\
0.50 \\
0.50 \\
0.50 \\
0.50 \\
0.50 \\
0.50 \\
0.51 \\
0.51 \\
0.51 \\
0.48 \\
0.48 \\
0.48\end{array}$ & $\begin{array}{r}1.02 \\
0.90 \\
2.62 \\
0.50 \\
2.47 \\
5.29 \\
0.76 \\
5.11 \\
0.40 \\
1.44 \\
1.49 \\
2.07 \\
3.43 \\
2.78 \\
4.63 \\
7.76 . \\
4.58 \\
7.14 \\
10.34\end{array}$ & $\begin{array}{l}1.09 \\
0.68 \\
3.85 \\
0.73 \\
3.85 \\
3.85 \\
0.57 \\
3.85 \\
0.58 \\
1.52 \\
1.49 \\
1.49 \\
1.49 \\
1.21 \\
1.21 \\
1.21 \\
4.16 \\
4.16 \\
4.16\end{array}$ & $\begin{array}{r}<0.005 \\
<0.005 \\
<0.005 \\
<0.005 \\
<0.005 \\
0.082 \\
<0.005 \\
0.087 \\
<0.005 \\
<0.005 \\
<0.005 \\
<0.005 \\
0.248 \\
0.007 \\
0.330 \\
1.580 \\
0.077 \\
0.240 \\
1.340\end{array}$ & $\begin{array}{l}0.001 \\
0.001 \\
0.001 \\
0.001 \\
0.001 \\
0.038 \\
0.001 \\
0.040 \\
0.001 \\
0.001 \\
0.002 \\
0.002 \\
0.098 \\
0.004 \\
0.127 \\
0.314 \\
0.034 \\
0.093 \\
0.275\end{array}$ \\
\hline
\end{tabular}


loadings 'are listed in Table 7.15. For feed with the estimated maximum nitrate loading, approximately five times the nominal amount of formic acid would be required. To minimize the volume of formic acid required for redox adjustments, sugar may be added as an additional source of reduced carbon. Current design is based on a maximum of $30 \mathrm{ml} 90 \mathrm{wt} \%$ formic acid per liter of feed.

It is estimated that a significant amount $(-50 \%)$ of nitrate may be converted to nitrite via radiolysis reactions. The $\mathrm{HCOOH} / \mathrm{NO}_{2}^{-}$requirement is expected to be less because $\mathrm{NO}_{2}^{-}$is in a lower oxidation state than $\mathrm{NO}_{3}{ }^{-}$. Differences in kinetics and reaction mechanisms could result in differences in gas composition and release rates. Characterization and formating of actual DST waste currently being conducted at PNL will provide an estimate of the waste nitrite and nitrate content. Glass redox adjustments will also be evaluated. However, supplemental data collected from cold simulants containing nitrite and off gas compositional data is required to support this single data point.

\subsection{MASS BALANCE}

Development of a predictive model for glass redox $\left(\mathrm{Fe}^{+2} / \mathrm{Fe}^{+3}\right)$ as a function of the amount of formic acid added and feed composition necessitates the spanning of two different chemistry systems: 1) formating during which

TABLE 7.15. Formic Acid Requirements Based on Reference Nitrate Loadings (a)

\begin{tabular}{|c|c|c|c|c|}
\hline \multirow[b]{2}{*}{ Leve1 } & \multicolumn{2}{|c|}{ Nitrate Concentration } & \multicolumn{2}{|c|}{$\begin{array}{l}\text { Formic Acid } \\
\text { Requirements, ml }(90 \mathrm{wt} \%) / \mathrm{L}\end{array}$} \\
\hline & $\mathrm{g} \mathrm{NO}_{3} / 100 \mathrm{~g} \mathrm{WO}$ & moles $\mathrm{NO}_{3} / \mathrm{L}$ & $\mathrm{HCOOH} / \mathrm{NO}_{3}=3$ & $\mathrm{HCOOH} / \mathrm{NO}_{3}=4$ \\
\hline Low & 3 & 0.07 & 9 & 12 \\
\hline Nominal & 9 & 0.20 & 27 & 37 \\
\hline High & 36 & 0.78 & 108 & 143 \\
\hline
\end{tabular}

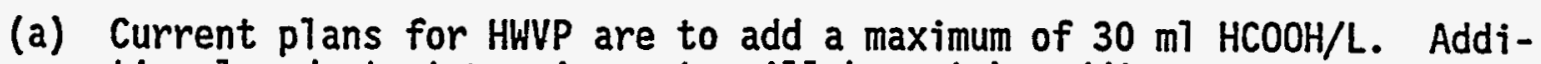
tional reductant requirements wiTl be met by adding sugar. 
the formic acid is added and 2) vitrification, the product from which the $\mathrm{Fe}^{+2} / \mathrm{Fe}^{+3}$ is measured. The presence of oxidized $\left(\mathrm{e} . \mathrm{g} ., \mathrm{CO}_{2}\right)$ and reduced (e.g., $\mathrm{NO}_{2}, \mathrm{NH}_{3}$ ) species in the off gas suggests that redox reactions take place in both systems.

To establish a relationship between the products of both systems, a preliminary mass balance spreadsheet was developed for Runs 12 and 13 . (refer to Table 7.16). Corresponding flowsheets are shown in Figures 7.5 and 7.6. The analytical data available for this flowsheet development are the initial concentration of nitrate and ferric ion in the simulant; the amount of formic acid added; the concentration of nitrate after formic acid addition and reflux (i.e., prior to vitrification); and the $\mathrm{Fe}^{+2} / \mathrm{Fe}^{+3}$ ratio in the vitrified sample. Off gases shown for the formating step in Figures 7.6 and 7.7 $\left(\mathrm{H}_{2}, \mathrm{CO}_{2}, \mathrm{~N}_{2} \mathrm{O}\right.$ and $\left.\mathrm{NO}_{x}\right)$ were reported by Hiemers (1987). $\mathrm{NH}_{3}$ was observed in formated simulants prepared in the current study. Goles and Nakaoka (1989) reported $\mathrm{H}_{2}, \mathrm{CO}_{2}, \mathrm{CO}, \mathrm{SO}_{x}, \mathrm{NO}_{x}$, and $\mathrm{NH}_{3}$ in the off gas of the melter.

The amount of reduced carbon (formate or formic acid) leaving the formating step was estimated based on the amount of nitrate reduced (assuming NH3 to be the end product):(a)

Reduced Carbon ("HCOOH") to metter $=\mathrm{HCOOH}$ added $-[4$ * nitrate reacted].

Both of these runs satisfied the requirements, $\mathrm{HCOOH} / \mathrm{NO}_{3} \geq 3$ and $\mathrm{Fe} / \mathrm{NO}_{3}<4$, prescribed for obtaining a $\mathrm{Fe}+2 / \mathrm{Fe}^{+3} \geq 0.005$. Comparison of the run data indicates that the amount of nitrate reduced during the formating step is greater for low carbonate, high nitrate sample. For example, at approximately equivalent $\mathrm{HCOOH} / \mathrm{NO}_{3}(-4.6)$, the moles of nitrate consumed per mole of formic acid added during formating was 0.20 for Sample 2, Run 12 compared with 0.0075 for Sample 1, Run 13. This effect may, be due 1) a concentration effect on the reaction equilibrium imposed by the higher nitrate concentration (0.42 $\underline{M}$ for Run 12 versus $0.115 M$ for Run 13) and/or

(a) Assuming the nitrate reduction product as $\mathrm{NH}_{3}$ maximizes the estimate of carbon utilization in the formating step. The amount of ammonia produced was not quantified in this study. 
TABLE 7.16. Mass Balance Spreadsheet

Run 12 (Low Carbonate Loading) Preformate Sample 1 Sample 2 Sample 3

$\mathrm{NO}_{3}$ initial, $\underline{\mathrm{M}}$

$\mathrm{NO}_{3}$ remaining, $\underline{M}(\mathrm{a})$

0.42

Total $\mathrm{NO}_{3}$ consumed, $M(a, b)$

0.155

0.036

0.151

0.265

0.384

0.269

$\mathrm{HCOOH}$ added, $\underline{M}$

1.17

0.11

1.95

0.41

3.27

$\mathrm{HCOOH}$ remaining, $M(a, c)$

1.06

1.54

2.19

$\mathrm{HCOOH}$ consumed, $\underline{M}(a, b)$

0.51

$\mathrm{Fe}^{+3}$ initial, $\mathrm{M}$

Giass $\mathrm{Fe}^{+2}, \underline{M}$

$\begin{array}{lll}0.004 & 0.13 & 0.31\end{array}$

$\mathrm{HCOOH} / \mathrm{NO}_{3} / \mathrm{Gl}^{+3}$

2.8

0.007

4.6

0.33

7.8

1.58

Percent Efficiency for Nitrate Reduction in Formating Step

$\mathrm{NO}_{3}$ consumed/ $\mathrm{HCOOH}$ added

23

20

8.2

Percent Efficiency for $\mathrm{Fe}+3$ Reduction

$\mathrm{Fe}^{+2}$ produced/HCOOH added

0.3

6.7

9

Run 13 (high carbonate loading)

$\mathrm{NO}_{3}$ initial, $\mathrm{M}$

$\mathrm{NO}_{3}$ remaining, $\mathrm{M}(\mathrm{a})$

Total $\mathrm{NO}_{3}$ consumed, $\mathrm{M}(\mathrm{a}, \mathrm{b})$

0.115

$\mathrm{HCOOH}$ added, $\underline{M}$

$\mathrm{HCOOH}$ remaining, $M(a, c)$

$\mathrm{HCOOH}$ consumed, $M(a, b)$

0.111

0.004

0.057

0.002

$\mathrm{Fe}^{+3}$ initial, $\mathrm{M}$

0.53

0.058

0.113

Glass $\mathrm{Fe}^{+2}, \underline{M}$

0.48

$\mathrm{HCOOH} / \mathrm{NO}_{3}$
$\mathrm{Gl}$ ass $\mathrm{Fe}^{+2} / \mathrm{Fe}^{+3}$

0.51

0.82

1.19

0.02

0.59

0.74

$0.02 \quad 0.23 \quad 0.45$

Percent Efficiency for Nitrate Reduction in Formating Step

$\mathrm{NO}_{3}$ consumed/HCOOH added

0.75

7.1

9.5

Percent Efficiency for $\mathrm{Fe} \pm 3$ Reduction

$\mathrm{Fe}^{+2}$ produced/HCOOH added

$6.4 \quad 11.3$

24

(a) Refers to formating step, only.

(b) CaTculated by difference.

(c) Estimation based on nitrate consumption. Assumes $\mathrm{NH}_{3}$ product. 


\section{Formating $\longrightarrow$ Uitrification}

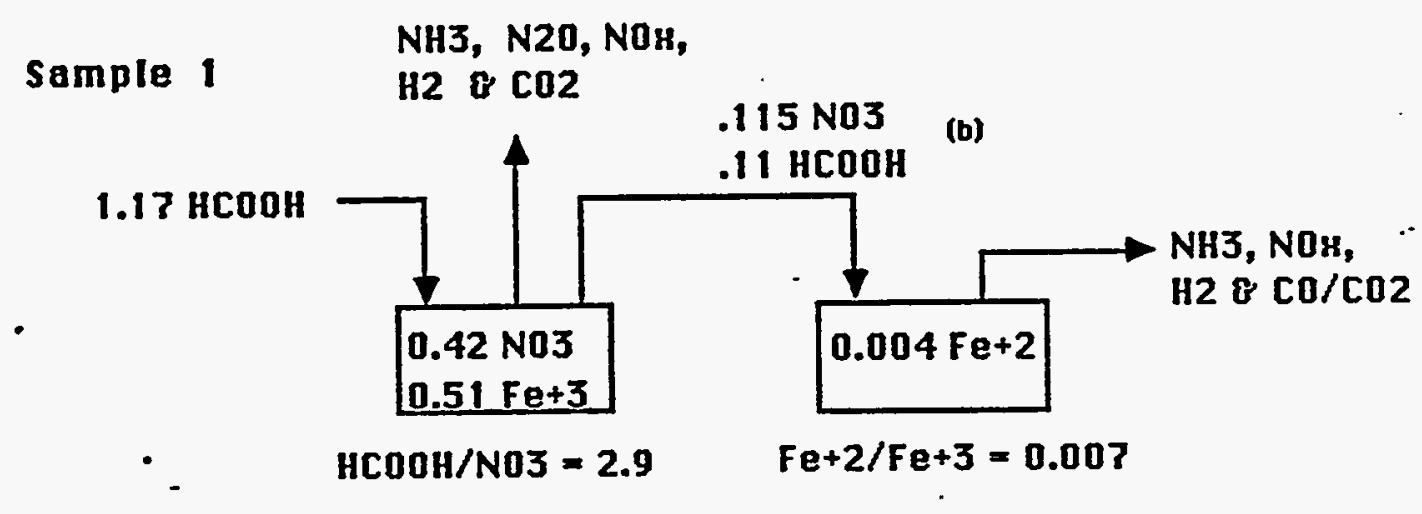

Sample 2 .

$1.95 \mathrm{HCOOH}$

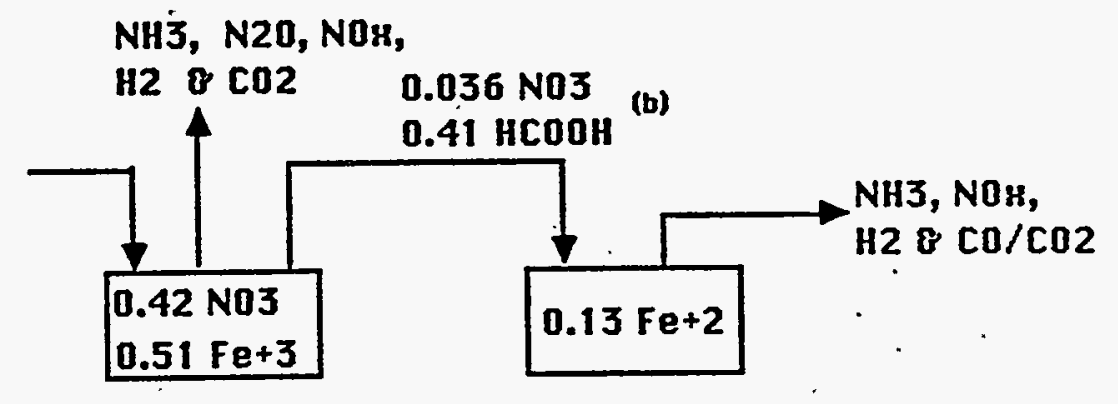

$\mathrm{HCOOH} / \mathrm{NO3}=4.6 \quad \mathrm{Fe}+2 / \mathrm{Fe}+3=0.33$

Sample 3

$\mathrm{NH3}, \mathrm{N2O}, \mathrm{NOH}$,

$3.27 \mathrm{HCOOH}$

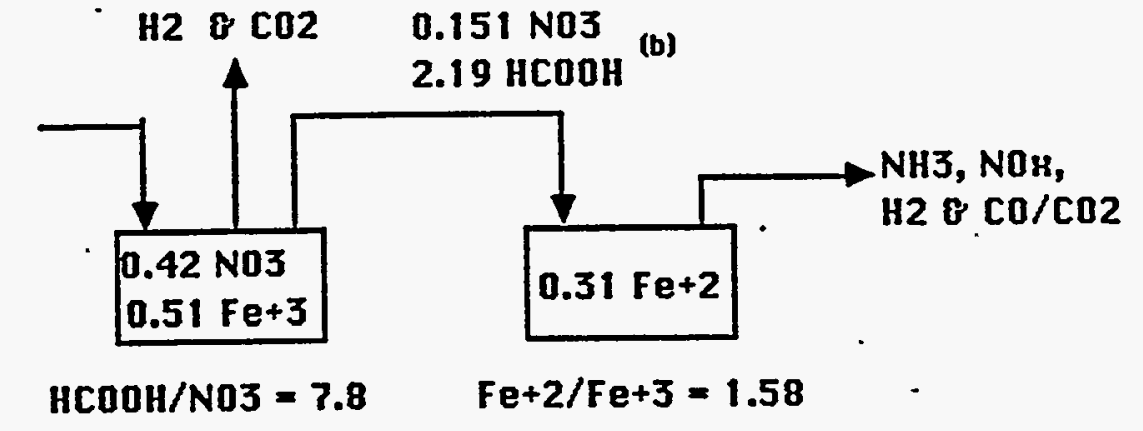

(a) Amounts eupressed in moles/L.

(b) Estimation based on nitrate consumption. Assumes NH3 as end product which minimizes carbon to melter.

FIGURE 7.5. Preliminary Mass Balance Flowsheet for Run 12 


\section{. Formating $\longrightarrow$ Uitrification}
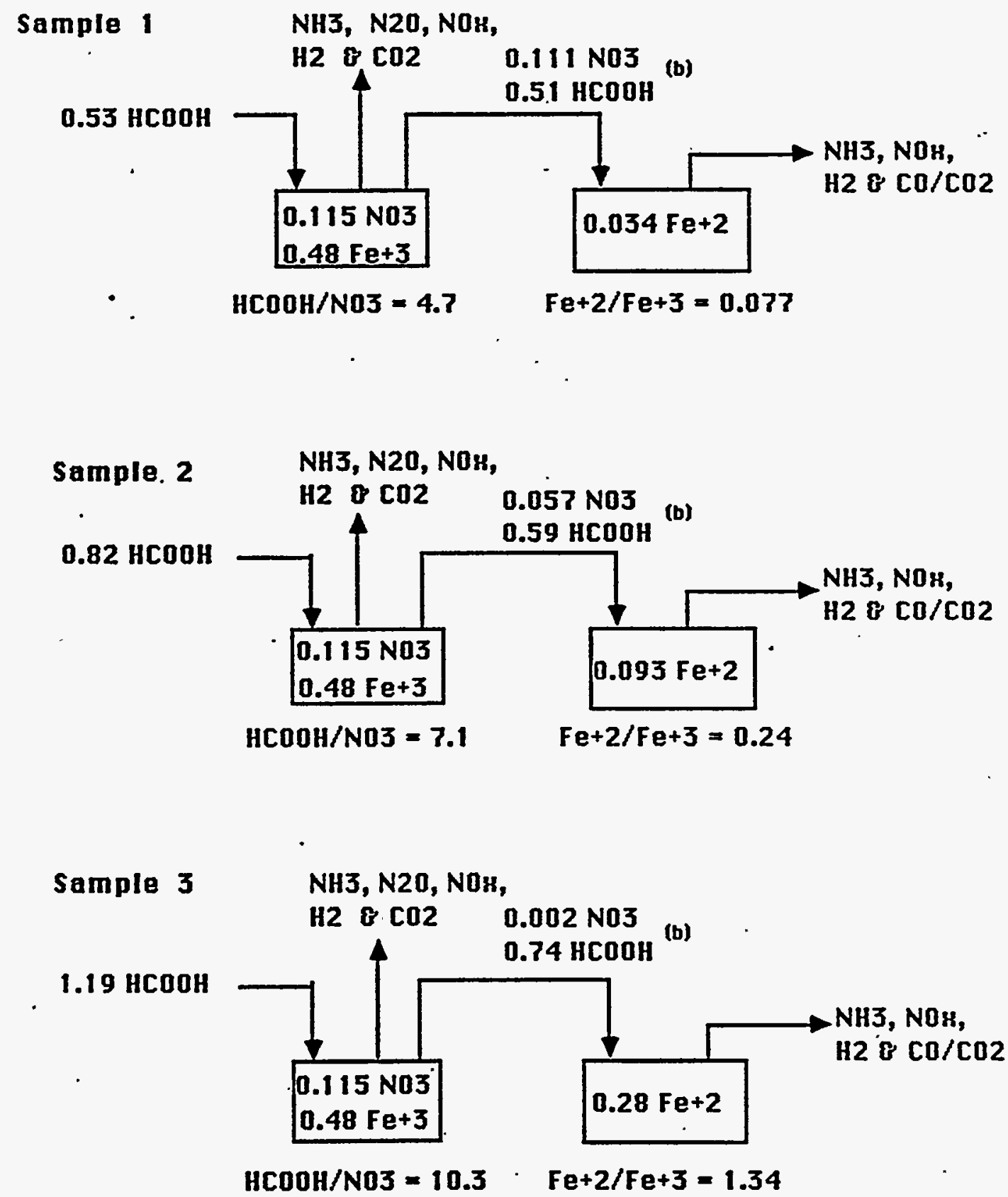

(a) Amounts eupressed in moles/L.

(b) Estimation besed on nitrote consumption. Assumes NH3 as end product which minimizes carbo to melter.

FIGURE 7.6. Preliminary Mass Balance Flowsheet for Run 13 


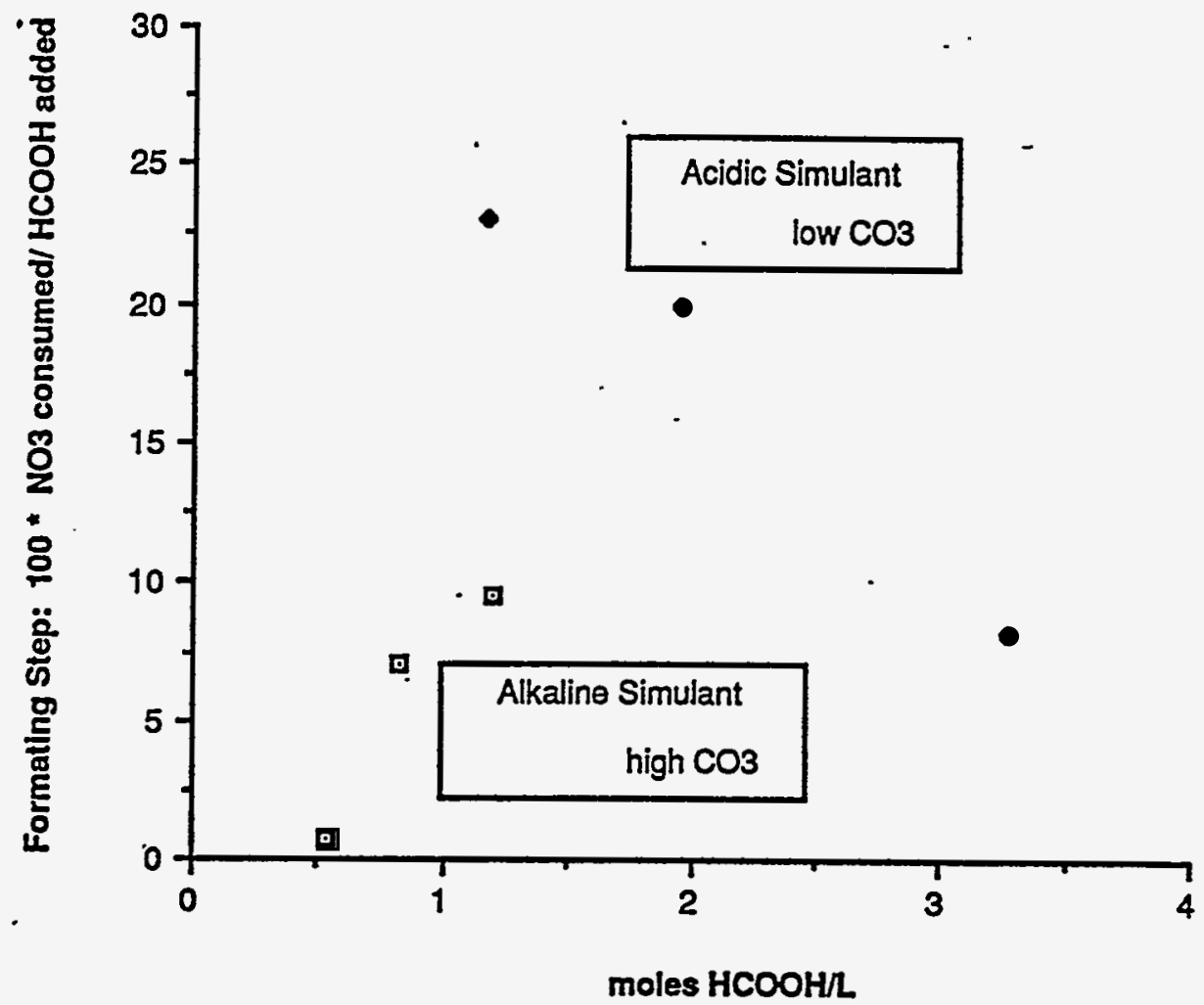

FIGURE 7.7. Nitrate Reduction Efficiency During Formating

2) the higher acidity of the low carbonate run (minimum pH for Run 12: 364; Run 13: 5-7). As discussed in Section 7:3.1 and Wiemers (1987) the redox potentials for reactions of interest are $\mathrm{pH}$ dependent. . Figure 7.7 illustrates graphicaliy the dependence of nitrate reduction during formating on carbonate concentration. It is speculated that to satisfy the threshold for $\mathrm{Fe}^{+3}$ reduction $>0.5 \%\left(\mathrm{HCOOH} / \mathrm{NO}_{3}=3\right)$, the remaining nitrate is consumed during vitrification.

At equivalent $\mathrm{HCOOH} / \mathrm{NO}_{3}$, the amount of $\mathrm{Fe} \mathrm{e}^{+2}$ present in the vitrified sample per mole of formic acid added during formating (\% efficiency for $\mathrm{Fe}^{+3}$ reduction), is independent of the carbonate and nitrate content. For example, at approximately equivalent $\mathrm{HCOOH}_{\mathrm{NO}}$, the \% efficiency for $\dot{\mathrm{F} e}{ }^{+3}$ reduction is 6.7 for Sample 2, Run 12 and 6.4 for Sample 1, Run 13. A7so, for Sample 3 , Run 12 , the \% efficiency for $\mathrm{Fe}^{+3}$ reduction is 9 which is reasonabiy close 11.3 for Sample 2; Run 13. Run 12 had low carbonate loading, while Run 13 has high carbonate loading. Figure 7.8 illustrates graphically 


\section{HWVP 1990, Runs 1-13}

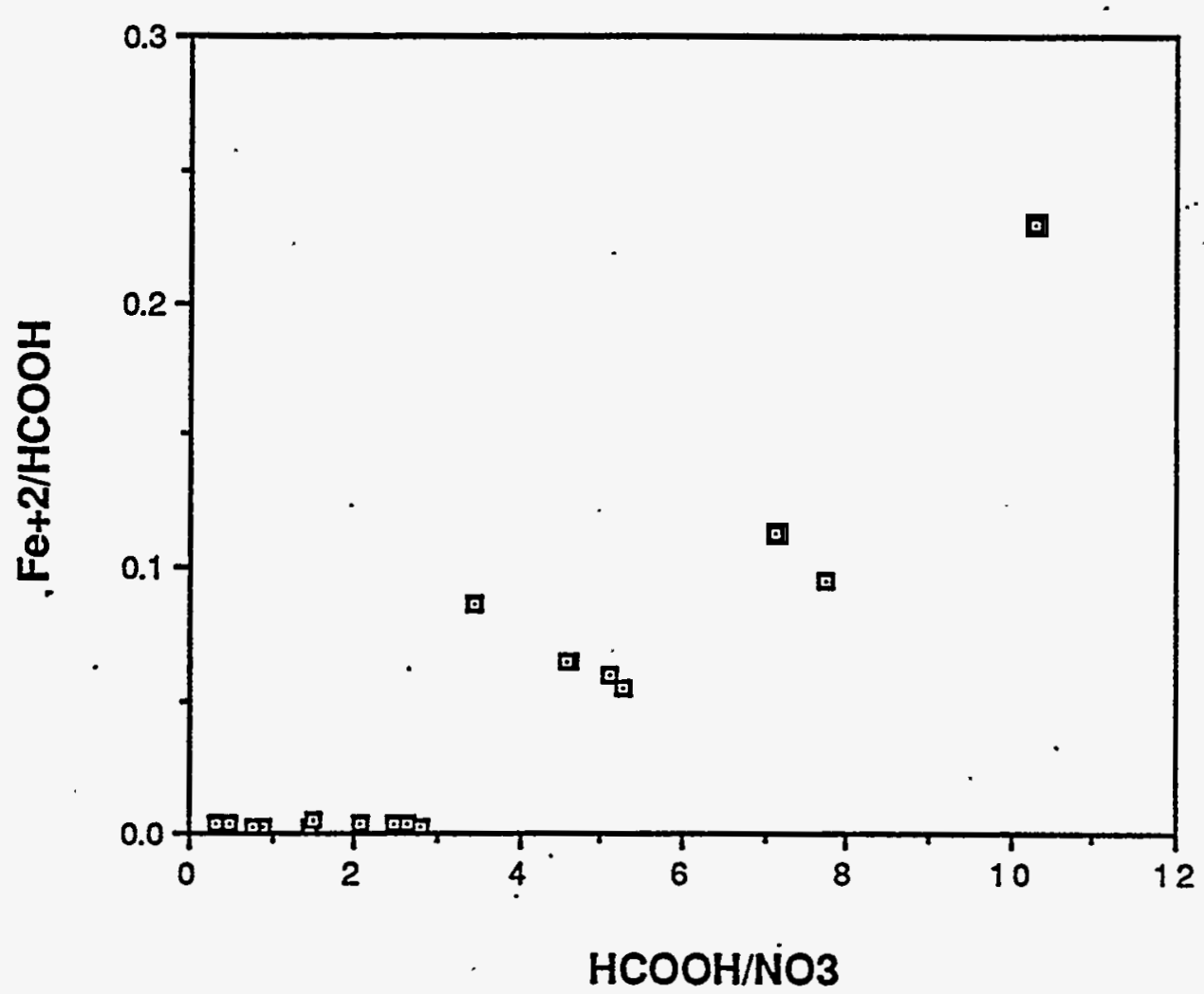

FIGURE 7.8. Relationship Between Ferrous Ion, Nitrate, and Formic Acid

the threshold value, $\mathrm{HCOOH} / \mathrm{NO}_{3}=3$ discussed previously and the fairly linear relationship between the moles of $\mathrm{Fe}^{+2}$ produced per mole of formic acid added as a function of $\mathrm{HCOOH} / \mathrm{NO}_{3}$. Data from Runs $1-13$ is included in Figure 7.8.

The following scenario describing the relationship between the formic acid, nitrate, ferric ion, and carbonate is based on the above observations. The reduction of nitrate and ferric ion by formic acid are two competing reactions. At the loadings specified for the reference feed composition $\left(\mathrm{Fe} e^{+3} / \mathrm{NO}_{3} \leq 4\right)$, the relationship, $\mathrm{HCOOH} / \mathrm{NO}_{3}=3$, must be satisfied before an equilibrium is reached yielding $\geq 0.5 \%$ of the ferric ion reduced to ferrous ion in the vitrified sample. The extent to which nitrate is reduced during formating (rather than during vitrification) depends on the $\mathrm{pH}$; which is dependent on the carbonate content. The \% nitrate reduction during formating ranged from 4 to $98 \%$. Because the threshold for $\mathrm{HCOOH} / \mathrm{NO}_{3}$ is independent of 
the carbonate concentration, it is assumed that the same amount of nitrate is reduced independent of which step, vitrification or formating, the reduction reaction takes $\mathrm{place}$. The implications of this suggestion for HWVP design relate to the 'most favorable step for release of the product gases. 


\subsection{HWVP APPLICATION}

It has been demonstrated that nitrate content of pretreated NCAW does affect the glass redox adjustment requirements. In a nitrite- and organicfree feed simulant, where $\mathrm{Fe}^{+3} / \mathrm{NO}_{3} \leq 4$, three moles of formic acid are required per mole of nitrate to obtain an acceptable reduction of $\mathrm{Fe}^{+3}$. $(\geq 0.5 \%)$. The effect of additional active redox participants on formic acid requirements. remains to be established.

Secondary effects related to feed composition and laboratory vitrification conditions likely affect glass redox as implied by the data scatter in Figure 7.4. Quantitative relationships are not fully defined without further considering the SRAT and melter metals chemistry.

The formic acid requirement for glass redox adjustment was independent of carbonate feed content. However, carbonate may affect the HWVP operations from another perspective. Preliminary data (two data sets) suggests that by buffering the $\mathrm{pH}$ in the alkaline range, high carbonate loading results in less reduction of nitrate (i.e., less gas release) occurs during formating. With low carbonate loading and the resultant lower feed acidity, a larger. amount of nitrate is reduced during formating. The impact of preferential release of gases may affect feed preparation steps and criteria.

Design considerations related to several qualitative observations recorded during this study are listed below. These observations are discussed in detail in Section 6.0.

- Ammonia was an end product of nitrate reduction by formic acid. The release rate of noxious $\left(\mathrm{NH}_{3}, \mathrm{NO}_{x}, \mathrm{SO}_{x}\right.$, and $\left.\mathrm{CO}\right)$ and explosive $\left(\mathrm{H}_{2}\right.$, $\mathrm{CO}$ and $\mathrm{NH}_{3}$ as $\mathrm{NH}_{4} \mathrm{NO}_{3}$ ) gases from the SRAT and melter need to be further defined to assess environmental emissions and potential hazards.

- The effect of magnetic solids in the formated feed on subsequent processing steps requires further consideration.

- An apparent dilatant melter feed resulted from feed formated to the level required for obtaining an acceptable $\mathrm{Fe}^{+2} / \mathrm{Fe}^{+3}$. value in high nitrate feed. Addition. of sugar for supplemental reductant capacity would minimize the formic acid requirements. However, the rheology of feed to which sugar is added to minimize formic acid requirements shouid be considered. 


\subsection{QUALITY ASSURANCE}

Work authorized by this test $\mathrm{plan}$ was conducted in accordance with Impact Level II requirements as identified in Quality Assurance P7an No. WTC-006, latest revision for the HWVP. Test P7an, HWVP-89-1VJ0010300A was developed to support testing activities. All laboratory data, genera?. observations, and details of the activities performed per this test plan were recorded in 1aboratory record books BNS \#50597 and 53567.

ICP and $\mathrm{Fe}^{+2} / \mathrm{Fe}^{+3}$ analyses was completed in accordance with guidance provided in SOW number M43108A. TIC and TC analyses was to be completed in accordance with guidance provided in SOH number M43108B and IC analyses per SOW number M43108C and M43108A. 


\subsection{REFERENCES}

Baes, C. F. and R. F. Mesmer. 1986. The Hydrolysis of Cations. Robert E. Krieger Publishing Company.

Bradley, R. F. and C. B. Goodlett. 1972. "Denitration of Nitric Acid Solutions by Formic Acid, "DP-1299, Savannah River Laboratory, Aiken, South Carolina.

Bray, L. A. 1963. Denitration of Purex Wastes With Sugar, Report No. HW-76973, General Electric Company, Hanford Atomic Products Operation, Richland, Washington.

Burger, L. L. December 1989. Pacific Northwest Laboratories, Private communication.

Cotton, F., Albert and Geoffrey Hilkenson. 1966. Advanced Inorganic Chemistry. A Comprehensive Test, Interscience Publishers.

Elinson, S. V. and K. I. Petrov. 1965. Analytical Chemistry of Zirconium and Hafnium. Halsted Press.

Farnsworth, R. K. 1987. The Effect of Feed Composition and Formic Acid Addition on Glass Redox State, Letter Report to Hestinghouse Hanford Company, No. HWVP-87-V110203A, Prepared by Pacific Northwest Laboratory, Richland, Washington.

Farnsworth, R. K., C. M. Ruecker, J. M. Perez, H. T: BTair, G. T. Thornton, B. A. Pulsipher, and D. McCarthy. 1986. Hanford Waste Vitrification PIant Feed Process Variability Testing for Fiscal Year 1986, Letter Report to Westinghouse Hanford Company, No. RHO-RE-CR-16P/HWVP-V1123C, Prepared by Pacific Northwest Laboratory, Richiand, Washington.

Gibson, H. H. 1969. "The Chemistry of Formic Acid and Its Simple Derivatives," Chem Rev. 89, 673.

Goles, R. W. and R. K. Nakaoka. January 1989. Hanford Waste Vitrification Program Pilot-Scale Ceramic Melter Test 23, Technica7 Report to Westinghouse Hanford Company, HWVP-89-IVJ0010100B, Prepared by Pacific Northwest Laboratory, Richland, Hashington.

Healy, T. V. September 1958. "The Reaction of Nitric Acid with Formaldehyde and with Formic Acid and Its Application to the Removal of Nitric Acid from Mixtures," J. Appl. Chem. 8 .

Latimer, H. M. and J. H. Hildebrand. 1951. Reference Book of Inorganic Chemistry, third edition, The MacMillan Company. 
Longstaff, J. V. L. and K. Singer. 1954. "The Kinetics of Oxidation of Nitrous Acid and Nitric Acid. Part II. Oxidation of Formic Acid in Aqueous Nitric Acid," J. Chem. Soc., p 2610.

Mahler, H. R. and E. H. Cordes. 1966. Biological Chemistry, Harper and Row.

Thorne, P. L. L. and E. R. Roberts. 1948. Fritz Ephraim, Inorganic Chemistry," Interscience Publishers, Inc.

Thornton, G. T. 1987. Evaluation and Comparison of HWVP and Comparison of HWVP-Reference Féed Composition and Updated Neutral ized Current Acid Waste Composition Simulants. HWVP-87-V110203C, Pacific Northwest Laboratory, Richland, Washington.

Wiemers, K. D., C. A. Anderson, and M. E. Peterson. 1987. Evaluation of Process Off Gases Released During the Formating of an HWVP Feed Simulant, Letter Report to Hestinghouse Hanford Company, No. HWVP-87-V110203G, Prepared by Pacific Northwest Laboratory, Richland, Washington.

Wright, G. D. 1988. Hanford Waste Vitrification PTant Technical Data Package, SD-HWV-DP-001, Rev. 4, Westinghouse Hanford Company, Richland, Hashington.

Zamecnik, J. 1989. IDMS Testing Update Presentation. "Defense Waste Processing Technology Savannah River Laboratory." November 15, 1989. 